\title{
The Medicinal Properties and Phytochemistry of Plants of the Genus Terminalia (Combretaceae)
}

\author{
I. E. Cock ${ }^{\mathrm{a}, \mathrm{b}^{*}}$ \\ aBiomolecular and Physical Sciences, Nathan Campus, Griffith University, 170 \\ Kessels Rd, Nathan, Brisbane, Queensland 4111, Australia \\ ${ }^{\text {b} E n v i r o n m e n t a l ~ F u t u r e s ~ C e n t r e, ~ N a t h a n ~ C a m p u s, ~ G r i f f i t h ~ U n i v e r s i t y, ~} 170$ Kessels Rd, \\ Nathan, Brisbane, Queensland 4111, Australia
}

*Corresponding author. Tel.: +61 7 37357637; fax: +61 737355282.

E-mail address: I.Cock@griffith.edu.au (I. E. Cock). 


\section{ABSTRACT}

Plants of the genus Terminalia are amongst the most widely used plants for traditional medicinal purposes worldwide. Many species are used for their antibacterial, antifungal, antiprotozoal, antiviral, antidiarrhoeal, analgesic, antimalarial, antioxidant, antiinflammatory and anticancer activities. Wound healing and cardiovascular effects have also been credited to some species. Many Terminalia species have multiple beneficial effects for multiple diseases and ailments. Indeed, the Indian species $T$. chebula is known as the king of plants in Ayurveda due to its broad range of medicinal uses. However, apart from the reported ethnopharmacological uses of many Terminalia species, surprisingly few studies have rigorously examined this important genus for their medical properties/mechanisms and phytochemistry. This is likely due to the high tannin content common to many Terminalia species and the perception that these tannins may be responsible for much of their beneficial properties. As the complexities of tannins make them poor candidates for drug design, most interest in Terminalia species has been for their pharmacognostic and nutraceutical value and they have often been overlooked as potentials for drug discovery. However, recent reports have identified many other interesting phytochemicals and demonstrated that these may be responsible for several of the reported bioactivities of the Terminalia species used in traditional medicinal systems. The last decade has seen a large increase in the number of studies into the use of Terminalia species as therapeutic agents. Several species used in Ayurvedic medicine (T. arjuna, T. bellerica, $T$. catappa, T. chebula) in particular have received much recent attention. Similarly, recent reports have also highlighted the medicinal potential of species from Africa, Australia and the Americas. The aim of this report is to summarise the recent research into the medicinal properties, phytochemistry and therapeutic mechanisms of Terminalia species and thus to highlight and direct future areas of research into the medicinal activities of this important genus.

KEYWORDS: Antioxidant, anticancer, inflammation, antimicrobial, diabetes, medicinal plants.

\section{INTRODUCTION}

Plants have a long history of usage as therapeutic agents and were the main source of medicines prior to the advances of modern medicine. In many developing countries, 
herbal medicinal systems remain important in the treatment of many ailments. Ayuvedic medicine is still commonly practiced within India with an estimated 85\% of Indians still using crude plant preparations for the treatment of a wide variety of diseases and ailments (Kamboj, 2000). Traditional Chinese medicine (TCM) and African medicinal systems also account for a major portion of health care in their populations. Even in countries where allopathic/Western medicine is dominant, much is also owed to plant medicinal systems. Furthermore, many users are returning to herbal medicinal systems due to the perception that natural medicines are often a safer alternative than allopathic drugs, as well as seeking treatments for diseases which modern medicine does not yet have solutions.

Many of the prescription drugs currently marketed for a wide variety of ailments were originally isolated from plants and/or are semi-synthetic analogues of phytochemicals. It has been estimated that approximately $25 \%$ of all prescription drugs currently in use are of plant origin (Walsh, 2003; Newman and Cragg, 2007). Furthermore, approximately 75\% of new anticancer drugs marketed between 1981 and 2006 were derived from plant compounds (Newman and Cragg, 2007). Traditionally, plant based medicines have been used as crude formulations such as infusions, tinctures and extracts, essential oils, powders, poultices and other herbal preparations. The current trend is to isolate and characterise the individual phytochemical components with the aim of producing an analogue of increased bioactivity/bioavailability. Such studies have given rise to many useful drugs such as quinine (from Cinchona spp.) and digoxin (from Digitalis spp.) as well as the anticancer drugs vincristine and vinblastine (from Vinca rosea). However, the bioactivities seen for crude extracts are often much enhanced, or even totally different to those seen for the individual components (Karalliedde and Gawarammana, 2008; Choi and Chung, 2003). Crude plant extracts may contain hundreds, or even thousands of different chemical constituents that interact in complex ways. Often it is not known how an extract works, even when its therapeutic benefit is well established.

The genus Terminalia (Family Combretaceae) comprises approximately 200-250 species of medium to large flowering trees, many of which have a history of usage in traditional medicinal systems (McGaw et al, 2001). Terminalia species are widely distributed through the tropical and subtropical regions of Asia, Australia and Africa. 
With arguably the greatest number and diversity, the Asian Terminalia's cover many of the most useful species with the most extensive documentation of their therapeutic effects. Asian Terminalia species are widespread, occurring from the Malaysian peninsula and the Indonesian archipelago in the east, across Southern Asia to Western Asia and into the Middle East. The biology of many of these species are especially well studied due to their usage in a variety of Asian medicinal systems. Of the species that are native to Asia, Terminalia arjuna and Terminalia chebula are particularly well documented due to their myriad of uses in Ayuverdic medicine. Approximately 28 species are known to occur in Australia and the South Pacific region. Of these, Terminalia ferdinandiana has been receiving recent attention due to its interesting phytochemistry and its high antioxidant content/activity. A further 30 species approximately occur in Africa, with the majority of these occurring in the southern part of the continent. A number of Terminalia species are also native to the North, Central and South America.

The bark of many Terminalia species is often fissured and the branches are arranged in tiers. The genus name is derived from the Latin word terminus, referring to the fact that the leaves are located at the very tips of the shoots. Leaves of most species of Terminalia are usually large and have a leathery feel. The small (usually) greenishwhite flowers appear on spikes or in clusters. Fruit may be yellow, dark red or black drupes which are usually angled or winged. The fruit from some plants is edible and may in fact be highly nutritious.

Many Terminalia species are renowned for their high antioxidant activities. Indeed, the Australian species Terminalia ferdinandiana has been reported to have the highest antioxidant activity of any plant worldwide (Netzel et al, 2007). Its ascorbic acid levels alone are more than 900 times higher than those of blueberry (g/g). Similarly, studies have also shown the Asian species T. chebula (Chang and Lin, 2012; Mety and Mathad, 2011; Hazra et al, 2010), T. belerica (Mety and Mathad, 2011; Hazra et al, 2010), T. paniculata (Agrawal et al, 2011), T. arjuna, T. catappa (Mety and Mathad, 2011), and the African species T. prunioides, T. brachystemma, T. gazensis, T. mollis and T. sambesiaca (Masoka and Eloff, 2007) to also have high antioxidant contents. 


\section{ETHNOPHARMACOLOGY}

Members of genus Terminalia have been used for a broad range of medicinal purposes by traditional healers from a wide variety of ethnic and cultural groupings (Table 1). The best documented of these are the traditional Indian medicinal systems, particularly the Ayurveda. Ayurvedic practitioners employ various species of Terminalia for a wide variety of medicinal purposes including abdominal and back pain, coughs and colds, conjunctivitis, diarrhoea and dysentery, fever, headache, heart disorders, inflammation, leprosy, pneumoniae, sexually transmitted diseases, worms, wounds, haemorrhages, ulcers, and as a general tonic. Of the Ayurvedic plants, $T$. arjuna, T. bellerica, T. chebula and T. catappa are arguably the most useful, being utilised for multiple ailments as summarised in Table 1 and discussed for each medicinal bioactivity.

Similarly, African medicinal systems made use of native Terminalia species in the treatment of multiple different disorders. Different species occur in different parts of the continent and their usage, whilst often widespread, is also often associated with specific cultural/ethnic groupings. Thus, a species used by one cultural grouping for a specific property may have had different therapeutic uses (or no uses) by other groups in different regions of the continent. T. ivorensis, T. avicennioides, T. glaucescens and T. macroptera, are amongst the most useful West African species, with documented ethnopharmacological uses for such diverse disorders as bacterial, fungal and viral diseases and infections, malaria, trypanosomiasis the treatment of coughs, bloody sputum and antimycobacterial activity. Similarly, many Terminalia species were used by diverse ethnic and cultural groupings in Southern and Central Africa. T. bentzoe, T. brachystemma, T. brownii, T. mollis, T. sericea, T. spinosa and T. stenostachya all have documented ethpharmacological uses in Southern Africa for the treatment of abdominal disorders, pain, bilharzia, cancer, coughs and colds, dysentry, diarrhoea, fever, venereal diseases, heart disorders, hypertension, jaundice, malaria, diabetes and for the treatment of bacterial, fungal and viral diseases. Indeed, the Southern African species T. mollis has even been linked with anti-HIV activity.

Despite a diverse range of Terminalia species in the Americas, (especially in tropical South American) and a history of usage in traditional medicine, there have been few studies on species from these continents. T. acuminata and T. triflora are perhaps the 
most promising Terminalia species based on their ethnobotanical usage. These species have been traditionally used to treat bacterial, fungal and viral diseases and infections. Indeed, T. triflora also has reputed anti-HIV activity and this activity has been scientifically verified and demonstrated to be due to the inhibitory effect of leaf extract components on the polymerase and ribonuclease activities of the HIV reverse transcriptase enzyme (Martino et al, 2002).

Less information is available about the ethnobotanical usage of Australian Terminalia species. Traditional indigenous Australian knowledge of plant based therapeutics was generally passed on orally, with little written ethnopharmacological record. Thus, as Australian Aboriginal culture merged into mainstream society, with a corresponding increased reliance on Western medicine, much of this knowledge has been lost. However, several species including Terminalia carpentariae, Terminalia hadleyana, Terminalia latipes and Terminalia ferdinandiana, are known to have been used both as food, and as medicinal plants (Cock, 2011; Lassak and McCarthy, 2006).

\section{PHYTOCHEMISTRY AND ANTIOXIDANT CONTENT}

Epidemiological studies have shown that a diet rich in antioxidants is associated with a decreased incidence of chronic diseases (Potter, 1997). High antioxidant levels have also been shown to act as a preventative against the development of degenerative diseases such as cancer (Hertog et al, 1996), cardiovascular diseases (Vita, 2005), neural degeneration (Youdim et al, 2002), diabetes and obesity (Tsuda et al, 2003). Phenolic compounds are generally strong antioxidants (Rice-Evans et al, 1997). Their primary action involves the protection of cell constituents against oxidative damage through the scavenging of free radicals, thereby averting their deleterious effects on nucleic acids, proteins, and lipids in cells (Rice-Evans et al, 1997). Phenolics interact directly with receptors or enzymes involved in signal transduction (Moskaug et al, 2005), clearly indicating that they play a specific role in human physiology. Common plant phenolic compounds include flavonoids, tannins, anthocyanins, and gallic acid, all of which are common phytochemical constituents of Terminalia species.

Recent studies have documented the exceptionally high antioxidant content of the Australian species T. ferdinandiana (Konczak et al 2010; Netzel et al, 2007). These studies have reported that the fruit of this plant has the highest ascorbic acid levels of 
any plant in the world, with levels reported as high as 6\% of the recorded wet weight (Woods, 1995; Miller et al, 1993). This is approximately 900 times higher (g/g) than the ascorbic acid content in blueberries (which were used as a standard). As a further comparison, oranges and grapefruit (which are considered good sources of ascorbic acid) only contain approximately $0.007 \%$ wet weight (0.5\% dry weight) (Johnson, 2003). Due to its high vitamin C levels, the primary use of $T$. ferdinandiana fruit is currently for production of vitamin $\mathrm{C}$ in health food, cosmetic, and pharmaceutical industries. However, T. ferdinandiana fruit also contains many other compounds which also contribute to its high antioxidant activity (Konczak et al 2010; Netzel et al, 2007). While many of these compounds are yet to be identified, T. ferdinandiana fruit has been shown to contain benzoic acids, flavanols, or flavanones (Konczak et al 2010). T. ferdinandiana fruit is a good source of gallic acid (Figure 1b) and ellagic acid (Figure 1c) (Cunningham et al, 2009; Cherikoff and Kowalski, 2008), which also demonstrate strong antioxidant activity in vitro (Losso et al, 2004; Ohno et al, 1999). T. ferdinandiana fruit is also very rich in chlorophyll a (Figure 1e) and chlorophyll b (Figure 1f), which have previously been shown to be capable of quenching oxidative stress (Motilva, 2008). Lipophilic T. ferdinandiana fruit extracts are also rich in lutein (Figure 1g-a carotenoid antioxidant compound associated with eye health) and with vitamin E (Figure 1d) and vitamin E analogs (Konczak et al, 2010). Hesperitin (Figure 1h), as well as the glycosides kaempferol (Figure 1i), luteolin (Figure 1j), and quercetin (Figure 1k) are some of the other antioxidants present in T. ferdinandiana fruit (Konczak et al, 2010). T. ferdinandiana fruit is also a good source of the minerals magnesium, zinc, calcium, potassium, sodium, iron, phosphorous, manganese, copper, and molybdenum (Konczak et al, 2010). It has previously been postulated that the exceptionally high antioxidant content of $T$. ferdinandiana fruit may be responsible for the therapeutic effects of this plant (Mohanty and Cock, 2012).

High antioxidant contents have also been reported for Asian Terminalia species (Hazra et al, 2010; Jaiwal et al, 2012; Mety and Mathad, 2011). One study reported the Trolox equivalent antioxidant content (TEAC) of Asian Terminalia as approximately 12.4, 1.6, 44.3 and $1.4 \mathrm{mg} / \mathrm{ml}$ extract for T. arjuna, T. belerica, $T$. catappa and T. chebula respectively (Jaiwal et al, 2012). Other studies have reported similarly high TEAC values for other Asian Terminalia species including $T$. paniculata (Agarwal et al, 2011) and T. alata (Mety and Mathad, 2011). Similarly, 
high antioxidant contents have also been reported for the African species $T$. brachystemma, T. gazensis, T. mollis, T. pruniodes, T. sambesiaca and T. sericea (Masoko and Eloff, 2007). The high antioxidant activities of plants of the genus Terminalia seem to correlate to their phenolic contents (Jaiwal et al, 2012). The high tannin and flavonoid contents characteristic of this genus have been suggested as being responsible for this activity (Chang and Lin, 2012; Jain et al, 2009). Indeed, the tannin antioxidant content of the Asian species T. chebula has been reported to be as high as $32 \%$ (Chattopadhyay and Battacharyya, 2007). The bioactivities of the individual components will be considered for each individual medicinal property discussed.

\section{CARDIOVASCULAR EFFECTS}

Ayurvedic practitioners employ several Terminalia preparations for the treatment of cardiovascular disorders and for their lipid lowering activities. Terminalia arjuna is considered particularly useful. The powdered tree bark is used to alleviate angina (Dwivedi and Udupa, 1989), possibly via its antioxidant activity. The stem bark contains high levels of antioxidant compounds including glycosides, flavonoids, tannins and inorganic minerals. Amongst the terpenoids reported in Terminalia arjuna bark are $\beta$-sitosterol (Figure 2a), terminic acid (Figure 2b) (Anjaneyulu and Prasad, 1983), terminoside A (Figure 2c), (Ali et al, 2003a, b) and arjunaphthanoloside. Terminoside $\mathrm{A}$ and arjunaphthanoloside are particularly interesting due to their reported therapeutic activities. Terminoside A inhibits nitric oxide production and decreases nitric oxide synthase levels in lipopolysaccharide stimulated macrophages, and arjunaphthanoloside possesses strong antioxidant activity (Ali et al. 2003a, b). T. arjuna bark also contains very high levels of antioxidant flavonoids compounds compared to other plants. Indeed, one study estimated the total flavonoid levels in $T$. arjuna bark to be $5698 \pm 531 \mathrm{mg} / 100 \mathrm{~g}$ compared to $1914 \pm 106 \mathrm{mg} / 100 \mathrm{~g}, 1255 \pm 119$ $\mathrm{mg} / 100 \mathrm{~g}, 1302 \pm 55 \mathrm{mg} / 100 \mathrm{~g}$ and $487 \pm 23 \mathrm{mg} / 100 \mathrm{~g}$ for cinnamon, tea leaves capsicum and turmeric respectively (Nair et al, 1996; Nair and Nagar, 1997). These flavonoids include arjunolone (Figure 2d), bicalein (Figure 2e), flavones, kampferol (Figure 1i), pelorgonidin (Figure 2f), quercetin (Figure 1k) (Sharma et al, 1982) and luteolin (Figure 1j) (Pettit et al, 1996). There is evidence that similar bioflavonoids prevent oxidation of LDL cholesterol via their free radical scavenging activity (Furman and Aviram, 2001), inhibit endothelial activation (Carluccio et al, 2003) and 
inhibit platelet aggregation (Ruff, 2003). They also possess cyclooxygenase inhibitory activity and can thus prevent thrombosis (Ruff, 2003). Evidence exists that high dietary levels of flavonoids are inversely proportional to the risk of coronary artery disease (CAD) (Martikainen et al, 2007; Middleton et al, 200; Peluso, 2006). It is therefore likely that high flavonoids contents in Terminalia species may be responsible for their beneficial effects in CAD.

In addition to the high flavonoids contents of plants of the genus Terminalia, another common phytochemical trait is the generally high tannin contents. Multiple hydrolysable tannins have been reported for T. arjuna, including pyrocatechols, punicallin (Figure 2g), punicalagin (Figure 3f), terchebulin (Figure 2h), terflavin C (figure 2i), castalagin (Figure 2j), casuariin and casuarinin (Figure 3d) (Lin et al, 2001). Tannins can enhance nitric oxide synthesis and relax vascular tissue stimulated to contract by norepinephrine and thus may be responsible at least in part for the hypotensive activity of T. arjuna bark (Nammi et al, 2003; Takahashi et al, 1997).

T. arjuna is a particularly interesting plant for the treatment of cardiovascular disorders due to its multiple modes of cardioprotection. Early studies have demonstrated that $T$. arjuna bark extracts increase the rate and force of cardiac contraction, as well as amplitude of contraction and the cardiac output (reviewed by Dwivedi, 2007). Furthermore, T. arjuna bark extracts also produce substantial ionotropic effects. Other effects noted for T. arjuna bark extracts include increases in coronary flow (Bhatia et al, 1998) and decreased blood pressure (Nammi et al, 2003; Takahashi et al, 1997). Furthermore, enhanced prostaglandin $\mathrm{E}_{2}\left(\mathrm{PGE}_{2}\right)$ activity has also been noted following T. arjuna treatment (Dwivedi et al, 1987). As PGE2 is known to produce coronary vasodilation, this increase may be responsible for the increased coronary flow following T. arjuna treatment (Bhatia et al, 1998). Bark extracts of T. arjuna also reverse cardiac injury (Tandon et al, 1995), have cardiovascular protective and tonic effects including improved cardiac cell mitochondrial uptake (Tandon et al, 1995), protection against oxidative stress (Gauthaman et al, 2001) and decreased levels of lipid peroxidise activity (Sivalokanathan et al, 2006). Further cardio-protective effects of T. arjuna bark include decreases in total lipid levels, especially LDL lipids, with a coincident increase in HDL lipids (Shaila et al, 1998; Khanna et al, 1996). 


\section{ANTIMICROBIAL ACTIVITY}

Many Terminalia species have a history of usage to treat medical conditions related to microbial infections and numerous recent investigations have reported on their antibacterial properties. Multiple studies have reported on the antibacterial properties of Terminalia species used in traditional Indian medicine. Leaf and bark extracts of arguably the best studied Terminalia species, Terminalia arjuna, have been reported in numerous studies to have antibacterial activity against a wide panel of microbes (Aneja et al, 2012; Shinde et al, 2009), partially justifying its use in the treatment of a wide range of diseases and medical disorders (Jain et al, 2009; Udupa, 1986: Tripathi and Singh, 1996). Terminalia chebula also has a tradition of use in Ayurveda for the treatment of numerous diseases and conditions (Chopra et al 1956; Nadkarni, 1976; Das, 1991). It is not surprising that $T$. chebula has also been reported to display potent antibacterial activity against a microbial panel (Aneja and Joshi, 2009). Similarly, Terminalia alata, Terminalia bellirica and Terminalia catappa have also been reported to have broad spectrum antibacterial activity (Shinde et al, 2009). Whilst none of these studies identified the antibacterial components, one study demonstrated that they were relatively nonpolar and that this activity was not due to tannin components (Shinde et al, 2009). In contrast, other studies have demonstrated antibacterial activity being associated with the polar extracts (Aneja et al, 2012; Aneja and Joshi, 2009).

The antibacterial activity of other Asian species has also been reported. Terminalia muelleri leaf components have been shown to inhibit the growth of several Staphylococcus aureus strains, including a methicillin resistant strain (Anam et al, 2010). This study also examined the antibacterial mechanism of these compounds and reported that the Terminalia muelleri leaf components induced similar morphological changes in the bacterial cells as were seen with vancomycin treatment of bacteria (shrinkage and thinning of the cell wall). From these studies the authors have reported the inhibition of the cell wall as a putative antibacterial mechanism for Terminalia muelleri leaf components.

Numerous African Terminalia species also have potent antibacterial activity. One study of the South East African species Terminalia stenostachya and Terminalia 
spinosa reported strong antibacterial activity against a broad spectrum of medicinally important bacteria including several Mycobacterium species, Streptococcus faecalis, Staphylococcus aureus, Vibrio cholera, Bacillus anthracis, Klebsiella pneumoniae, Salmonella typhi, Pseudomonas aeruginosa and Escherichia coli (Mbwambo et al, 2011). Terminalia brownii also has a history of usage in traditional eastern and central African medicinal systems, including usage for the treatment of diverse medicinal conditions including diarrhoea and gonorrhoea (Fyhrquist et al, 2002; Dhetchuvi and Lejoly, 1990). A recent report has confirmed the antibacterial activity of T. brownii against Staphylococcus aureus, Escherichia coli, Pseudomonas aeruginosa, Klebsiella pneumoniae, Salmonella typhi and Bacillus anthracis. The West African species Terminalia avicennioides, which is widely used in Nigerian traditional medicine (Gill and Akinwunmi, 1986), has been reported to have good antimicrobial activity towards a methicillin resistant strain of Staphylococcus aureus (Akinyemi et al, 2005). Further studies have identified a terpenoid, friedelin (Figure 3a), as the probable antibacterial component of Terminalia avicennioides. Similarly, recent studies have demonstrated the growth inhibitory activity of Terminalia sericea and Terminalia pruinoides against pathogenic (Cock and van Vuuren, 2015a) and food spoilage bacteria (Cock and van Vuuren, 2015b).

Terminalia ferdinandiana from Australia also has strong antibacterial activity against an extensive panel of bacteria. In a recent study, solvent extracts of various polarities were tested against both Gram-positive and Gram-negative bacteria (Cock and Mohanty, 2011). The polar extracts proved to be more effective antibacterial agents, indicating that the antibacterial components were polar compounds. Indeed, the polar extracts inhibited the growth of nearly every bacteria tested against. Both Grampositive and Gram-negative bacteria were susceptible, indicating that the inhibitory compounds readily crossed the Gram-negative cell wall. The individual antibacterial components were not identified in this study although the authors indicate the extremely high levels of antioxidants in Terminalia ferdinandiana fruit (including gallic (Figure 3b) and ellagic acids (Figure 3c)) may be responsible for this antibacterial activity.

Several bacterial species are can initiate autoimmune inflammatory diseases (Cock, 2015). Recent studies have highlighted the potential of Terminalia spp. as growth 
inhibitors of these bacteria and thus of the initial events of several autoimmune diseases. Terminalia ferdinandiana fruit is a potent inhibitor of Proteus mirabilis (Sirdaarta et al, 2015a), Acinetobacter baylyi and Pseudomanas aeruginosa growth (Sirdaarta et al, 2015b) and thus have potential in the prevention and treatment of rheumatoid arthritis and ankylosing spondylitis respectively. T. ferdinandiana leaf extracts have also been shown to be good inhibitors of these same bacteria, as well as of Klebsiella pneumoniae and therefore may also be useful in the prevention of ankylosing spondylitis (Courtney et al, 2015). Further studies have reported similar growth inhibitory activity for the South African species Terminalia sericea and Terminalia pruinoides against these microbial triggers of rheumatoid arthritis (Cock and van Vuuren, 2014) and ankylosing spondylitis (Cock and van Vuuren, 2015). In these studies, stilbene and tannin componentss have been identified as likely to contribute to this inhibitory activity.

In contrast, the antifungal, antiviral and antiprotozoal activities of Terminalia species have been less extensively studied. Antifungal activity has been reported for several species, although less quantitative data is available for the antifungal activity of Terminalia extracts compared to antibacterial activity. One study into the antifungal activity of several South African Terminalia species reported good antifungal activity for $T$. pruniodes, $T$. brachystemma, $T$. sericea, $T$. gazensis, $T$. mollis and $T$. sambesciaca against the fungal species Candida albicans, Cryptococcus neoformans, Aspergillus fumigates, Microsporum canis and Sporothrix schenkii (Masoko and Eloff, 2005). Indeed, particularly low MIC values between 0.2-0.8 $\mathrm{mg} / \mathrm{ml}$ were reported in this study, indicating the efficacy of Terminalia extracts. This was a particularly interesting study as the Cryptococcus and Candida strains used were multi-antibiotic resistant strains. As fungal infections cause significant mortality and morbidity in Africa (especially in immune-compromised individuals), this finding could potentially result in the development of life saving treatments. Whilst this study did not identify the bioactive compounds, it did demonstrate that tannins were unlikely to be responsible due to the non-polar nature of the antifungal components. Interestingly, little data is available on the antifungal activities of Terminalia species from other world regions and much work is needed in this area. In my own laboratory, the Australian species Terminalia ferdinandiana has been tested against a limited panel of fungi (including Candida albicans and Aspergillus niger) and has shown no 
antifungal activity against any species tested (unpublished results). However, the fungal species tested were nystatin resistant strains and only a very limited panel was screened. Therefore, it is possible that further studies may detect antifungal activity for this plant against other fungi.

Whilst limited studies have evaluated the antifungal activity of the Terminalia, several reports document their antiviral potential. Cheng et al (2002) reported that a tannin compound isolated from the bark of Terminalia arjuna displayed potent inhibitory activity against herpes simplex virus type 2 (HSV-2). This study identified this compound as the hydrolysable tannin casuarinin (Figure 3d). The anti-herpes activity was also particularly long lasting, still evident 12 hours after viral infection. Furthermore, the Cheng study also exhibited a multifaceted antiviral activity for this compound. Casuarinin exposure prevented the attachment of HSV-2 to cells and blocked viral penetration, as well as inhibiting the late events of infection. Furthermore, casuarinin displayed good viricidal activity, with concentrations as low as $25 \mu \mathrm{M}$ reducing viral titres up to 100,000 fold.

Recent studies have also demonstrated the relatively good antiviral activity of Terminalia chebula towards measles and mumps viruses (Sumithira et al, 2012). Whilst this study did not examine the antiviral mechanism or identify the active components, it did demonstrate that the extracts contained high levels of phenolic antioxidant compounds. It was also demonstrated that the extract was not toxic to Vero cells. Another recent study reported that the Terminalia chebula leaf extracts also have potent inhibitory activity against herpes simplex virus type 1 (HSV-1) (Lin et al, 2011). The hydrolysable tannins chebulagic acid (Figure 3e) and punicalagin (Figure 3f) were identified as the extract components responsible for this antiviral activity. Chebulagic acid and punicalagin inhibit HSV-1 entry into A549 lung cells in a multifaceted manner: they prevent binding of the virus to cells, viral penetration, cell to cell spread, as well as secondary infection. These compounds were shown to target the interaction between cellular glycosaminoglycans and HSV-1 glycoproteins

A South American species (Terminalia triflora) has been shown to have viral antiinfective activity against HIV in HLT4LacZ-IIIB cell cultures (Martino et al, 2002). This activity was demonstrated to be due to the inhibitory effect of leaf extract 
components on the polymerase and ribonuclease activities of the HIV reverse transcriptase enzyme. Furthermore, this study isolated the antiviral activity to a hydrophilic tannin containing fraction, indicating that tannins may be responsible for the antiinfective activity. Earlier studies have also reported that leaf extracts from this plant have antiviral activity against several other RNA viruses including rabies, foot and mouth disease and influenza (Planes de Babchero and Souto, 1969; Rivas and Distefano, 1973; Rivas et al, 1971). The African species Terminalia mollis (stem and root extracts) has also been reported to have anti-HIV activity against virus type 1 (HIV-1, III $_{\mathrm{B}}$ strain) (Maregesi et al, 2009). This study did not report on the anti-HIV mechanisms or the active components.

The best studied antiprotozoal activities of the genus Terminalia are the antimalarial and antitrypanosomiasis (sleeping sickness) bioactivities. Several species including Terminalia mollis (Maregesi et al, 2009), Terminalia catappa (Mudi and Muhammad, 2009), Terminalia chebula and Terminalia bellerica (Pinmai et al, 2010) have been reported to have activity against Plasmodium falciparum. Terminalia avicennoides (Alayande et al, 2011) and Tereminalia ivorensis (Agbedahunsi et al, 2006) have been reported to have to have inhibitory activity towards Trypanosomiasis brucei (the parasite responsible for sleeping sickness). Terminalia bellerica has also demonstrated trypanocidal activity against the related organism Trypanosma evansi (Shaba et al, 2009a; Shaba et al, 2009b) although no reports were found of its activity against Trypanosomiasis brucei. None of these studies examined the antiprotozoal mechanism, nor did any report identify the bioactive compounds. Recently, the Australian species $T$. ferdinandiana was reported to be a potent inhibitor of the gastrointestinal protozoan parasite Giardia duodenalis and a number of bioactive components were identified (Rayan et al, 2015). Studies into the anti-Giardiasis activity of other Terminalia spp. are lacking and much further work is required to screen other species for this activity.

\section{ANTIINFLAMMATORY ACTIVITY AND IMMUNOMODULATION}

Inflammation is a complex response by the body to injury. It typically follows a variety of insults including burns, wounds, bites and stings etc. It is characterised by a wide variety of symptoms (Macpherson, 1992) including: 
- Swelling. Injury may result in increased capillary permeability which allows leukocyte migration and fluid accumulation in the damaged tissue. This accumulation results in the swelling characteristic of inflammation.

- Redness and heat are caused by vasodilation, reducing blood pressure and increasing circulation.

- Pain is a complex reaction resulting from the release of short peptides and prostaglandins.

As Terminalia species contain multiple active phytochemicals, many with antioxidant activity, it is likely that several of these may be required to address different aspects of the inflammatory process. The inflammatory processes require the cellular release of several classes of molecules. Vasoactive substances (eg. bradykinin, prostaglandins, and vasoactive amines) are required to dilate blood vessels, opening junctions between cells to allow leukocytes to pass through capillaries. Any compound capable of blocking these vasoactive substances would potentially have a therapeutic effect as an anti-inflammatory agent. $\beta$-sitosterol (Figure 2a) is an abundant phytosterol in several Terminalia species (Anjaneyulu and Prasad, 1982a, b). $\beta$-sitosterol stimulates smooth muscle cells to release prostacyclin ( $\mathrm{PGI}_{2}$ ) (Awad et al, 2004). Conversely, $\beta$-sitosterol treatment blocks the release of $\mathrm{PGI}_{2}$ and prostaglandin $\mathrm{E}_{2}\left(\mathrm{PGE}_{2}\right)$ from macrophages (Awad et al, 2004). Thus, $\beta$-sitosterol treatment would be expected to affect vasodilation and therefore have a therapeutic effect on inflammation.

Recent studies have reported that $T$. arjuna leaf extracts have potent antiinflammatory activity in vivo (Biswas et al, 2011). This anti-inflammatory effect is likely due to the inhibition of the enzyme cyclooxygenase, resulting in the inhibition of prostaglandin synthesis (Biswas et al, 2011). Chebulagic acid (figure 4a) isolated from T. chebula extracts also has potent anti-inflammatory effects in LPS-stimulated RAW 264.7 (mouse macrophage) cells via its antioxidant activity (Reddy and Reddanna, 2009). These effects are exerted via a down regulation of cyclooxygenase2 (COX-2) and 5-lipoxygenase (5-LOX), tumor necrosis factor-alpha (TNF- $\alpha$ ) and interleukin-6 (IL-6) (Reddy and Reddanna, 2009; Reddy et al, 2009). This down regulation results in the inhibition of the inflammatory mediators such as nitric oxide 
(NO) and prostaglandin $\mathrm{E}_{2}\left(\mathrm{PGE}_{2}\right)$ production. Thus chebulagic acid exerts antiinflammatory effects. As mitogen-activated protein kinases (MAPKs) which regulate inflammatory and immune responses may be activated by the production of reactive oxygen species (ROS), it is likely that the inhibition of ROS via chebulagic acids antiinflammatory activity is involved.

Potent anti-inflammatory activity has also been reported for the African species $T$. sericea (Moshi and Mbwambo, 2005). The triterpenoidal saponin sericoside (Figure 4b) has been isolated from $T$. sericea extracts and is believed to be responsible for this activity (Mochizuki and Hasegawa, 2007; Rode et al, 2003). Indeed, pure sericoside pretreatment in vivo has been shown to decrease the extent and severity of colon inflammation colitis in an induced inflammatory bowel disease (IBD) experimental model (Mochizuki and Hasegawa, 2007). As superoxide radical $\left(\mathrm{O}_{2}{ }^{-}\right)$is generated in IBD model systems (Kankri et al, 2001) and sericoside has potent antioxidant activity (Mochizuki and Hasegawa, 2007), it is likely that T. sericea's anti-inflammatory activity is due at least in part to its free radical scavenging activity.

Chemotactic factors which include several proteins and peptides are also required to increase cell motility, especially the motility of leukocytes during inflammation. Blocking these chemotactic factors or blocking their effects prevents inflammatory swelling. Crude $T$. sericea extracts, as well as the purified component sericoside, have been shown to block chemotaxis. In vivo administration of sericoside to SpragueDawley rats prior to IBD induction results in a significant reduction in neutrophil activation and infiltration into the colon mucosa (Mochizuki and Hasegawa, 2007). Furthermore, chebulagic acid isolated from T. chebula decreases cytokine production and IL-6 expression in human lymphoblastic T lymphocytes (Das et al, 2012), thereby decreasing chemotaxis. T. chebula extract treatment also results in decreased expression levels of TNF- $\alpha$ in Jurkat cells, which would subsequently down-regulate other cytokines including IL-1 and IL-6 (Lin et al, 2010. The mechanistic details of the relationship between the antioxidant activity of the $T$. chebula extracts and these anti-inflammatory effects have not yet been extensively examined. Furthermore, these studies have not rigorously examined the dose dependent effect of these phytochemicals. 


\section{ANTICANCER ACTIVITY}

The growth and development of healthy cells depends on fine regulation of growth promoting and inhibiting pathways. Proto-oncogenes and tumour suppressor genes are responsible for encoding proteins that regulate cell division/cell cycle, as well as for the repair of damaged DNA and cell programmed death by apoptosis. Mutations within these genes have been implicated in the onset of cancer (Hanahan and Weinberg, 2000). Such mutations result in cells that no longer require external signals to proliferate. Furthermore, these cells fail to recognise signals that restrict cell division, resulting in uncontrolled cell growth. In tumour genesis, multiple genes may be altered and transmitted to daughter cells, which subsequently escape normal growth restraints and form a tumour, that may be benign or malignant.

The induction of oxidative stress has been linked with several types of cancer (Brown and Bricknell, 2001; Tome et al, 2001). Thus it is possible that the high antioxidant contents of many Terminalia species may inhibit cancer formation and/or progression. Chromosome instability is also a common feature of many of the cancers that have been linked with oxidative stress, suggesting that increased oxidative stress may contribute to development of genetic instability. Oxidative stress leading to genetic instability would result in the emergence of new tumour phenotypes. In such populations, a decrease in apoptosis but an increase in tumour growth and subsequent tumour progression is observable. Consumption of high levels of antioxidants (as are characteristic of Terminalia species) may block this genetic instability and thus block tumourgenesis.

Currently used anti-cancer agents for the treatment of established tumours (eg. doxorubicin, daunorubicin, mitomycin C, etoposide, cisplatin, arsenic trioxide, ionising radiation, photodynamic therapy) depend exclusively or in part on the production of ROS for cytotoxicity. Sensitivity of tumour cells to oxidative stress and/or apoptosis may affect treatment success (Davis et al, 2001; Ruefli et al, 2001). Studies indicate that WEHI7.2 mouse thymoma cells over expressing catalase (CAT38) or thioredoxin (THX) are resistant to glucocorticoid-induced apoptosis in vitro (Freemerman and Powis, 2000; Baker et al, 1997). This suggests that glucocorticoid-induced apoptosis occurs by a ROS dependant mechanism. Average 
tumour weights increased in severe combined immune-deficient (SCID) mouse tumour xenografts from cells over expressing catalase or thioredoxin (Baker et al, 1997). Tumours from both transfectants contained fewer apoptotic cells however mitotic cell numbers were similar. This suggests that cellular antioxidant over expression results in increased tumour size due to a decrease in apoptosis.

Studies into the antioxidant/prooxidant effects of extracts from other plant species have demonstrated that the ability of a plant extract to exert antioxidant activity depends on multiple factors. Aloe vera antioxidant components for example may function as either an antioxidant or an oxidant with their action being dependent upon their concentration (Cock, 2011). The Aloe vera anthraquinone aloe emodin exerts anti-oxidant behaviour at lower concentrations, yet acts as a pro-oxidant at high concentrations. In contrast, a different Aloe vera anthraquinone (aloin) has an antioxidant effect at higher concentrations, yet a pro-oxidant effect at low concentrations. Thus, Aloe vera extracts and components may act as either antioxidants or as oxidants, dependent on differing levels of the various constituents, and on their ratios. Thus, although many Terminalia species have very high antioxidant contents reported, it is possible that the individual components may act as either antioxidants or as oxidants and thus may also be effective in the treatment of cancer, as well as in its prevention at different concentrations.

Similar pro-oxidant effects have been reported for other anti-oxidant phytochemicals including flavonoids (Rahman et al, 1990) and tannins (Singh et al, 2001) which are present in high concentrations in many Terminalia species (Ahsan and Hadi, 1998). Previous studies have also shown that the presence of transition metal ions such as copper or iron in the extract can enhance the conversion of the anti-oxidant to the prooxidant state (Lastra and Villegas, 2007; Wu et al, 2008). The pro-oxidant/antioxidant effect of plant extracts is due to a balance between the free radical scavenging activities and reducing power of their phytochemical components. This can be explained using the antioxidant vitamin ascorbic acid (which is present in high levels in several Terminalia species) as an example. Although ascorbic acid has well characterised anti-oxidant bioactivities, it is also known to act as a pro-oxidant at high concentrations (Joel, 1995). This is due to the greater reducing power of ascorbic acid 
compared to its free radical scavenging activity. In the presence of transition metal ions, ascorbic acid will function as a reducing agent, reducing the metal ions. In this process, it is converted to a pro-oxidant. Therefore, high dietary intake of ascorbic acid in individuals with high iron levels (eg. premature infants) may result in unexpected health effects due to the induction of oxidative damage to susceptible biomolecules (Halliwell, 1996; Herbert et al, 1996; Samuni et al, 1983).

ROS based tumour therapy would cause tumour regression should the tumour cells not be apoptotic/oxidant-resistant cells. Therefore, if Terminalia antioxidant components are present in concentrations and ratios consistent with pro-oxidant activity, the extract would be expected to induce apoptosis and therefore would have anticancer activity. If the levels of components are consistent with a reducing environment, anti-oxidant activity would result and the extract would not have anticancer activity. Conversely, should the protocol be repeated on a tumour with apoptotic resistant/oxidant resistant cells, the converse would apply, where tumour progression would be observed.

The Australian species T. ferdinandiana has been receiving much recent attention due to its recently reported extremely high antioxidant content (Konczak et al, 2010; Netzel et al, 2007) and reports linking antioxidant levels and redox management with anticancer activity (Mohanty and Cock, 2012). A recent study has demonstrated that a T. ferdinandiana fruit extract rich in polyphenolic compounds displayed antiproliferative activity against a panel of cancer cell lines (Tan et al, 2012). The proliferation of normal cell lines was also seen to be inhibited in this study, although several cancer cell lines (particularly gastric and colorectal cancer cell lines) showed a higher sensitivity to the $T$. ferdinandiana fruit extract compared to the equivalent normal cell line. To understand the cancer cell viability suppression mechanisms of the $T$. ferdinandiana fruit extract, this study also examined the induction of apoptosis. The extract was shown to activate caspase-7 and caspase-9 as well as poly (ADPribose) polymerase (PARP), indicating that apoptosis induction is via an intrinsic pathway.

Similarly, the tannin casuarinin (Figure 3d) isolated from bark extracts of the Indian medicinal plant T. arjuna has been reported to induce apoptosis in human A549 lung 
cancer cell lines (Kuo et al, 2005). It was postulated that an enhanced Fas/APO-1 ratio and increases in membrane bound and soluble Fas ligands may be responsible for casuarinin’s apoptotic effect. Furthermore, casuarinin was also found to arrest cell cycle progression in the $G_{0} / G_{1}$ phase, possibly due to a p53 dependent induction of p21/WAF1.

The Ayurvedic medicine Triphala has cytotoxic effects against various cancer cell lines (Kaur et al, 2005), thymic lymphoma cells (Sandhya et al, 2006a), human breast cancer cell lines (Kaur et al, 2005; Sandhya et al, 2006a), human prostate cancer cell lines and human pancreatic cancer cell lines (Shi et al, 2008). Conversely, the cytotoxic effects of Triphala are negligible in various normal cell lines (Sandhya et al, 2006a; Sandhya et al, 2006b). Triphala comprises fruits of 3 plants including 2 Terminalia species ( $T$. chebula and $T$. belliricia). Whilst the individual cytotoxic constituents were not identified in any of these Triphala studies, it is noteworthy that all 3 fruits used in this preparation have high antioxidant levels and high gallic acid contents (Baliga, 2010). As pure gallic acid (Figure 1b) has been shown to have similar cytotoxic effects as Triphala towards the same cancer cell lines (Kaur et al, 2005, Ishihara and Sakagami, 2003, Sakaguchi et al, 1999), it is likely that gallic acid is at least in part responsible for the anticancer activity of Triphala.

T. belliricia extracts have also demonstrated growth inhibitory effects towards human A549 lung cancer cell lines and HepG2 hepatocarcinoma cell lines without the presence of the other plant components present in Triphala (Pinmai et al 2008). Furthermore, the $T$. belliricia extract also showed a synergistic effect with conventional anticancer chemotherapeutics, enhancing the cytotoxic activity of cisplatin and doxorubicin towards the cancer cell lines, indicating its potential as a synergistic cancer chemotherapeutic agent.

\section{WOUND HEALING}

Whilst antiinflammatory and antimicrobial bioactivities are complex processes requiring the synergistic action of several bioactivities, wound healing is more so. Wound healing is the result of several complex bioactivities including: 
- Inflammation

- Antiseptic bioactivity

- Cell growth and proliferation

- Matrix remodelling

The growth of endothelial, epithelial and fibroblast cells are critical in wound healing. As a first step, a fibrin clot is formed as a temporary repair. This step is vital as it helps avoid microbial infection which may retard the healing process. The wound is subsequently invaded by a variety of cell types, some which stimulate an inflammatory response, while others are directly involved in the repair mechanism (Davis et al, 1987). The effects of Terminalia extract components on inflammation processes and chemotaxis have already been discussed and will not be discussed further here. Wound repair itself occurs in three phases: the migration of epithelial cells and fibroblasts to the wound site, proliferation of cells and cellular maturation. It is likely that the wound healing effect of Terminalia extracts may involve the synergistic action of multiple components on several pathways.

Several Terminalia species have reported wound healing bioactivities. Of these, perhaps the best documented and the most extensively studied are the Asian Terminalia species used in Ayurvedic medicine. T. arjuna (Chaudhari and Mengi, 2006), T. chebula (Li et al, 2011; Suguna et al, 2002) and T. coriacea (Ali Khan et al, 2012) have all demonstrated an ability to hasten the wound healing process. As wound healing is a complex process involving several bioactivities, no single experimental model is adequate to evaluate wound healing and various individual bioactivities need to be considered. These include antimicrobial, antiinflammatory and immunomodulatory activities which have already been considered, as well as cell proliferative activity, and tissue and matrix remodelling.

T. arjuna demonstrates several bioactivities that are important for wound healing. Aside from its good broad spectrum antimicrobial activity (previously summarised in this review) it also has been shown to induce enhanced tensile strength in incision wounds as well as increasing the rate of epithelialisation of the wound (Rane and Mengi, 2003). Further studies to characterise the bioactive components (Chaudhari and Mengi, 2006) isolated the wound healing activities to 3 separate fractions. The 
fraction which induced the greatest rate of epithelialisation consisted almost exclusively of tannins, indicating that tannins are very important in wound healing processes. Incidentally, this fraction also had the greatest antimicrobial activity of the fractions tested. Treatment of excision wounds with this fraction resulted in the largest increase of hexosamine levels (a component of the extracellular matrix) compared to the other fractions. Together with cellular growth and proliferation, wound healing also requires matrix remodelling. Thus T. arjuna tannin components also appear to affect matrix formation. The remaining 2 fractions isolated from $T$. arjuna bark also increased the rate of wound healing compared to the control, but were significantly less effective than the high tannin containing fraction. Whilst these fractions also contained tannins, they additionally consisted of saponins and reducing sugars. As sugars are known to delay the wound healing process by decreasing tensile strength (Emanuel and Farber, 1988), the slower rate of healing induced by these 2 fractions may be due to their higher sugar contents.

Similarly, T. chebula treatment also enhances extracellular matrix formation in wounds. In vivo wound healing studies have demonstrated that $T$. chebula treatment enhances protein synthesis and the deposition of matrix proteins in the granulation tissues (Suguna et al, 2002). The levels of collagen were particular elevated during the early stages of healing. The deposition of collagen at the wound site enhances the tensile strength and thus the rate of healing (Balleisen et al, 1975). Furthermore, the same study also demonstrated an increase in the levels of the extracellular matrix components hexosamine and uronic acid following T. chebula treatment in the early stages of wound healing (when the extracellular matrix forms), followed by a return to normal levels in the later stages. In addition, $T$. chebula tannin extracts have been shown to have angiogenic potential, increasing the amount of newly formed capillaries during the inflammatory phase of wound healing, as well as increasing the degree of wound contraction in granulation tissue (Li et al, 2011).

Other Terminalia phenolic compounds have also been implicated in the wound healing effects of this genus. $\beta$-sitosterol (Figure 2a) and $\beta$-sitosterol glucosides (Figure 5a), which are common Terminalia phytochemicals, promote endothelial cell proliferation and angiogenesis (Moon et al, 1999) although their activity appears to be dependent on their redox states (Vivancos and Moreno, 2005). Reduced sterols have 
antioxidant activity and stimulate wound healing processes, whilst oxidised sterols are prooxidants and induce cell death. Therefore $\beta$-sitosterol and $\beta$-sitosterol glucosides have potential applications in wound management in their reduced state. Further phytochemicals with wound healing properties in T. coriacea extracts were identified as anthraquinone glycosides (Figure 5b), flavonoids and tannins (Ali Khan et al, 2012). Similar anthraquinone glycosides have also been reported to stimulate cellular proliferation (Choi et al, 2001; Lee et al, 1997; Yagi et al, 2002). It has been postulated that the proliferative effect of anthraquinone glycosides may be due to their high antioxidant activities (Araya-Maturana et al, 2008; Gomes et al, 2009).

The redox environment also affects cellular signal transduction, DNA and RNA synthesis, protein synthesis, enzyme activation, regulation of the cell cycle, ligand binding, DNA binding and nuclear translocation and therefore ultimately cell proliferation/death (Makino et al, 1999; Simons and Pratt, 1995). Transcription factors are active in their reduced form and their translocation to the nucleus is also redox dependent (Okamato et al, 1999). Studies have demonstrated that $T$. chebula treatment increases transcription and translation rates as well as DNA replication ( $\mathrm{Li}$ et al, 2011; Suguna et al, 2002). These studies also linked these increases to the very high antioxidant activity of $T$. chebula. A reducing environment favours cellular proliferation whilst an oxidising environment results in an increase in reactive oxygen species, initiating cell death (Mamilos et al, 1989; Kim et al, 1996). Therefore, as discussed for anticancer activity, conditions favouring antioxidant activity would be expected to favour cellular proliferation whilst conditions favouring prooxidant activity would favour cell death. As high antioxidant contents are a common feature of plants of the genus Terminalia, it is not surprising that several Terminalia species have reported wound healing properties. It is likely that a synergistic action is required by several Terminalia extract components on multiple wound healing associated bioactivities.

\section{ANTIDIABETIC ACTIVITY}

Diabetes mellitus refers to a group of metabolic disorders that result in increased blood glucose concentrations, either because the pancreas does not produce enough functional insulin (type 1 diabetes), or because cells do not respond to the insulin which is produced (type 2 diabetes). The causes of diabetes mellitus include the auto- 
immune destruction of pancreatic cells (Betterle et al, 1984), viral infections (Yoon et al, 1979), genetic and environmental factors (Pyke, 1977), insulin or insulin receptor gene mutations (Tager, 1984), and altered pancreatic prostaglandin metabolism Robertson and Chen, 1977). Diabetes has significant health effects, impacting on the quality of life and life expectancy of those suffering with it.

Glycosylation of blood proteins including haemoglobin, albumin and lipoproteins is characteristic of diabetes mellitus (Klein, 1995). Under the hyperglycaemic conditions of diabetes mellitus, blood glucose interacts with specific amino acids on the surface of proteins, forming glycosylated protein products. These may undergo a series of further chemical modifications, resulting in the production of advanced glycation end products (AGE) (Singh et al, 2001b). The binding of AGEs to their receptors results in altered cell signalling which in turn results in free radical production (Penckofer et al, 2002). Indeed, diabetes mellitus has been shown experimentally to be associated with an increase in free radical formation and an associated decrease in antioxidant potential (Davi et al, 1999; Vessby et al, 2002). Studies have directly linked oxidative stress with the impaired maintenance of glucose homeostasis and the enhanced lipid peroxidation seen in diabetes mellitus (Davi et al, 1999). Furthermore, increased total antioxidant levels have been measured in the blood and saliva of diabetic patients, further supporting the proposed role of oxidative stress in diabetes mellitus (Astaneie et al, 2005).

Oxidative stress induction has also been suggested to be the common link between the diverse medical complications (including cardiovascular disease, renal and neural degeneration, impaired vision and erectile dysfunction) seen in diabetes mellitus (Rahimi et al, 2005; Shih et al, 2002). Therefore, treatment with antioxidants would be expected to counteract many of these complications. High antioxidant contents are a common feature for plants of the Terminalia genus. All Terminalia species have a number of compounds (both phenolics and nonphenolic compounds) that can act as antioxidants. Many phenolic compounds could potentially behave as either antioxidant or prooxidant dependant on their concentration, redox state and ratio between compounds (Cock, 2012). 
Several studies have indicated the beneficial effects of Terminalia species in diabetic patients. T. glaucescens is used in traditional Cameroon medicinal systems in the treatment of diabetes. Administration of T. glaucescens leaf extracts to streptozotocintreated mice has been shown to have a protective effect, inhibiting the hyperglycaemic effect of streptozotocin and blocking the induction of diabetes (Njomen et al, 2009). Phytochemical analysis of the T. glaucescens leaf extract revealed the presence of triterpenoids, flavonoids, tannins and alkaloid components, although the study did not determine the nature of the active components. Whilst the antidiabetic mechanism of the T. glaucescens leaf extract was also not determined, it has been suggested that the extract components may act either by directly competing with streptozotocin for binding to cellular glucose receptors (Crouch et al, 1978), or alternatively by directly activating superoxide dismutase, thus blocking the toxic effects of streptozotocin on the $\beta$ cells of the pancreas (Sandler and Andersson 1982; Robbins et al, 1980) and allowing for normal insulin production/secretion. Phytochemical evaluations of T. glaucescens bark extracts have identified glaucinoic acid, arjunic acid (Figure 6a), arjungenin (Figure 6b), sericoside (Figure 4b) and friedelin (Figure 3a) in the extract (Rahman et al, 2005). This study also reported the inhibition of $\beta$-glucuronidase activity by each of these compounds. As the enzyme $\beta$ glucuronidase is involved with carbohydrate breakdown, these compounds may also be capable of altering the activity of other enzymes involved in carbohydrate metabolism, thus affecting the maintenance of glucose homeostasis in diabetes mellitus.

A further study into the medicinal properties of another West African species, $T$. superba, reported that a hydroethanolic root extract displayed potent $\alpha$-amylase inhibitory activity (Momo et el, 2009). As $\alpha$-amylase is involved in the breakdown of carbohydrate $\alpha \quad(1 \rightarrow 4)$ glycosidic bonds, it functions to increase glucose bioavailability in the blood. As T. superba root extract blocks this enzyme, it would reduce the bioavailability of glucose and thus be useful in the treatment of diabetes. Furthermore, this $\alpha$-amylase inhibitory activity was correlated to the antioxidant activity of the tannin, flavonoid and phenolic acid components of the extract. Similarly, anti $\alpha$-amylase and anti $\alpha$-glucosidase activities have been reported for the Southern African species, T. sericea (Nkobole, 2009). This study identified $\beta$ sitosterol (Figure 2a), $\beta$-sitosterol-3-acetate (Figure 6c), lupeol (Figure 6d), stigma-4- 
ene-3-one, catechin (Figure 6e), epicatechin (Figure 6f), gallocatechin (Figure 6g) and epigallocatechin (Figure 6h) as the extract components with the anti $\alpha$-amylase and anti $\alpha$-glucosidase activities, and showed $\beta$-sitosterol and lupeol as having the strongest activity.

Antidiabetic activities have also been reported for several Asian Terminalia species including T. arjuna (Ragavan and Kumari, 2006), T. bellerica (Kannan et al, 2012; Kasabri et al, 2010), T. catappa (Ahmed et al, 2005; Nagappa et al, 2003), T. chebula (Kumar et al, 2006; Rao et al, 2006), T. pallida (Rao et al, 2003) and T. paniculata (Ramachandran et al, 2012). T. chebula ethanolic extracts were found to decrease the levels of blood glucose and glycosylated haemoglobin in a streptozocin induced diabetic rat model (Kumar et al, 2006). The extract also demonstrated inhibitory activity against the gluconeogenic enzymes glucose-6-phosphatase and fructose-1,6bisphophatase, and stimulated hexokinase activity. Further studies have also shown inhibitory activity of $\alpha$-glucosidase activity by $T$. chebula extracts and linked this inhibition to the antioxidant activity of chebulagic acid (Figure 3e), chebulinic acid (Figure 6i) and corilagin (Figure 7d) (Sasidharan et al, 2012). Studies into the antidiabetic activity of $T$. arjuna bark extract in diabetic rats demonstrated that the extract reduced lipid peroxidation and significantly increased the activities in the enzymatic antioxidants superoxide dismutase, catalase, glutathione peroxidise, glutathione-S-transferase and glutathione reductase, as well as increasing the nonenzymatic antioxidants reduced glutathione, vitamin A, vitamin E, ascorbic acid, total sulfhydryl groups (TSH) and nonprotein sulfhydryl groups (NPSH) in hepatic and renal tissue (Ragavan and Kumari, 2006).

T. bellerica methanolic extract treatment also blocks hyperglycaemia in diabetic rats via its antioxidant activity (Sabu and Kuttan, 2009). Significant decreases in ROS, as well as increased glutathione, superoxide dismutase, catalase, glutathione peroxidise and glutathione reductase activities were reported in diabetic rats following $T$. bellerica extract administration. An aqueous extract of $T$. bellerica fruits was shown to stimulate insulin secretion from a pancreatic $\beta$-cell line to a similar extent to glibenclamide (Kasabri et al, 2009). Furthermore, the aqueous extract also displayed insulin mimetic activity, enhancing glucose uptake into 3T3-L1 adipocytes and decreasing starch digestion and protein glycation. 


\section{PROTECTION AGAINST TOXIC COMPOUNDS}

Acetaminophen (paracetemol) is an effective analgesic and antipyretic drug. However, accidental or deliberate overdose may cause hepatotoxicity, resulting in liver damage and death. Whilst the mechanism of hepatic injury is not fully understood, it is thought that acetoaminophen is converted to the reactive metabolite $\mathrm{N}$-acetyl-p-benzoquinone imine (NAPQI) which is usually conjugated with glutathione in the liver to form the nontoxic compound mercapturic acid. When the concentration of acetoaminophen is elevated during an overdose, the glutathione is rapidly depleted and thus is no longer available to conjugate further NAPQI. Instead, the excess NAPQI binds to hepatic proteins and DNA, resulting in elevated levels of lipid peroxidation and ultimately cellular necrosis (Jueschke and Knight, 2003). T. paniculata extracts have recently been reported to alter the levels of biomarkers of hepatoxicity in vivo, indicating a hepatoprotective activity (Eesha et al, 2011). The $T$. paniculata extract was shown to protect the liver by blocking lipid peroxidation which leads to tissue damage when the cellular antioxidant defences are overwhelmed, indicating that the protective mechanism may be due to the high antioxidant content of T. paniculata extracts. Furthermore, the extract was also shown to induce significant increases in blood and hepatic thiol contents, providing the hepatic cells with increased protection against the NAPQI induced oxidative stress. Phytochemical screening in this study revealed the presence of high levels of flavonoids in the extract. As flavonoids are hepatoprotective via their antioxidant activities (Wilma et al, 2011), it is likely that the high flavonoids content of $T$. paniculata extract may contribute to its hepatoprotective activity.

T. arjuna has also demonstrated hepatoprotective and renal-protective activity towards oxidative stress induced by exogenous drugs (Manna et al, 2006). Pretreatment of mice with aqueous $T$. arjuna extract prior to exposure to the hepatotoxin carbon tetrachloride $\left(\mathrm{CCl}_{4}\right)$ blocked the decrease in the levels of the cellular antioxidants glutathione, superoxide dismutase, catalase and glutathione-Stransferase normally seen with $\mathrm{CCl}_{4}$ exposure. Thus T. arjuna treatment blocked oxidative stress related free radical hepatocyte damage. This study did not identify the phytochemical(s) responsible for this protective effect. However, as the mechanism appears to at least in part involve protection against reactive oxygen 
species (ROS), it is likely that the high antioxidant levels characteristic to this and other Terminalia species are involved.

\section{OTHER THERAPEUTIC ACTIVITIES}

A variety of other therapeutic properties have also been reported for Terminalia species. Indian and African Terminalia species have documented analgesic effects. Recent studies have reported analgesic activity in T. arjuna (Biswas et al, 2011) and T. superba (Dongmo et al, 2006) in mice using hot plate and formalin bioassays. In both studies, the reported analgesic effect was approximately the same efficacy as recorded for acetylsalicylic acid. The T. arjuna study also examined the antiinflammatory activity of the analgesic extract, reporting significant activity in an assay designed to evaluate the enzyme cyclooxygenase which is responsible for prostaglandin synthesis (Biswas et al, 2011). Whilst this study examined T. arjuna leaf extracts, other studies have reported the presence of $\beta$-sitosterol (Figure 2a), terminic acid (Figure 2b), (Anjaneyulu and Prasad, 1983), terminoside A (Figure 2c), arjunaphthanoloside (Ali et al, 2003a, b), arjunolone (Figure 2d), bicalein (Figure 2e), flavones, kampferol (Figure 1i), pelorgonidin (Figure 2f), quercetin (Figure 1k) (Sharma et al, 1982), luteolin (Figure 1j) (Pettit et al, 1996), punicallin (Figure 2g), punicalagin (Figure 3f), terchebulin (Figure 2 h), terflavin (figure 2 i), castalagin (Figure 2j), casuariin and casuarinin (Figure 3d) (Lin et al, 2001) in T. arjuna bark extracts. Many of these compounds have well established antiinflammatory potential. Similarly, the T. superba study also noted the presence of terpenoids, flavonoids and tannins in the analgesic fraction (Dongmo et al, 2006). It is thus likely that the reported analgesic effects of these two species in this experimental system may be due to their antiinflammatory activity and that these classes of compounds may be responsible.

T. chebula extracts have also been reported to have neuroprotective potential (Chang and Lin, 2012). Polar T. chebula extracts blocked $\mathrm{H}_{2} \mathrm{O}_{2}$ induced cell death in PC12 cells in a dose dependant manner. Indeed, the extracts not only blocked cell death, but also demonstrated cell proliferative activity. This study demonstrated that the cell protective and proliferative activities were highest in the extracts with high antioxidant contents, indicating that redox control in likely involved (Chang and Lin, 2012). Phytochemical analysis of $T$. chebula showed the presence of multiple 
phytochemicals with antioxidant activity including gallic acid (Figure 1b), ellagic acid Figure 1c), tannic acid (Figure 7a), ethyl gallate (Figure 7b), chebulic acid (Figure 7c), chebulagic acid (Figure 3e), corilagin (Figure 7d), mannitol and ascorbic acid (Figure 1a) (Grover and Bala, 1992). As gallic acid has demonstrated the ability to induce phosphorylation of c-Jun N-terminal protein kinase and the downregulation of Bcl-2 in PC12 cells, it was initially believed that gallic acid may be responsible for these activities (Chang and Lin, 2012). However, the same study demonstrated that pure gallic acid alone does not protect PC12 cells against $\mathrm{H}_{2} \mathrm{O}_{2}$ induced cell death. Instead, it has been postulated that the neuroprotective and cell proliferative activities of $T$. chebula extracts may be due to the $\cdot \mathrm{OH}$ and $\mathrm{H}_{2} \mathrm{O}_{2}$ scavenging activities of the tannin and phenolic mixture in the extract. Thus the synergistic action of multiple components may be responsible for the observed activities.

Schistosomiasis (bilharziosis) is a disease caused by parasitic trematodes. Whilst schistosomiasis has a low mortality rate, it is often a chronic illness that may result in damage to internal organs and may retard physical and mental development in children. Unfortunately, it appears that the schistosoma parasite is developing a resistance to praziquantel (the current gold standard drug) so further treatments and controls are required (Chitrsulo et al, 2000). A recent study has examined the molluscicidal action of T. catappa against the snail hosts of schistosomiasis and reported good molluscidal activity (Adentunji and Salawu, 2010). As an earlier ethnobotanical study has also reported T. catappa extracts to have antihelminthic activity (Corner, 1997), there is the possibility of a multifaceted approach to schistosomiasis control using T. catappa extracts, although this has yet to be verified.

T. catappa extracts also have potential in the treatment of sickle cell disease (SCD). This disease is characterised by haemolytic anaemia due to erythrocyte polymerisation and haemolysis under hypoxic conditions. The cells become rigid and sickle shaped with an increased tendency to adhere to the endothelium, resulting in vaso-occlusion. As erythrocytes are more prone to haemolysis in SCD, sufferers are also often anaemic (Aliyu et al, 2007). T. catappa has long been used to treat SCD in Western African traditional medicine and has been shown to inhibit haemolysis (Mgbemene et al, 1999) and to stimulate erythrocyte production (Aimola et al, 2011), validating their usage as a traditional medicine. The active extract was shown to 
contain alkaloids and anthraquinones and the authors postulated that these may be acting synergistically to elicit their haematopoetic and erythropoetic effects. Thus $T$. catappa extracts have potential in alleviating some of the symptoms of SCD.

\section{CONCLUSIONS}

This survey of the traditional medicinal and pharmacognosy literature has highlighted the therapeutic importance of this useful genus of plants. Various Terminalia species have been widely used in such diverse traditional medicine systems as Ayurveda, Siddha, Traditional Chinese Medicine (TCM), Western, Southern and Central African medicinal systems, multiple traditional systems from the tropical regions of the Americas, as well as various Australian Aboriginal medicinal systems.

Despite this history of traditional usage, until recently, rigorous scientific research has been confined to the study of only a few species. Of these, the Ayurvedic medicinal plants (especially T. arjuna, T. bellerica, T. chebula and T. catappa) have received the most attention. In these species, multiple therapeutic bioactivities have been documented. These species have been reported to have good antioxidant, anticancer, antidiabetic, antiseptic, cardiotonic and antiinflammatory effects as well as assisting in wound healing. In some cases the active phytochemicals have been established, although for many medicinal properties the active principles have been only partially characterised. Instead, often the partially purified compounds of a crude extract are itemised yet the active component(s) not identified. In other studies, the active compounds have not been characterised and instead only the classes of compounds in the crude mixture have been determined. Much work is still required to fully understand the phytochemistry of the genus Terminalia. Even for the more extensively studied species, much work is needed to fully determine the extent of the medicinal properties and the phytochemistry. Furthermore, few of these studies have provided substantial mechanistic detail to explain how the active principles achieve their medicinal effects.

The scope for future pharmacognostic studies is perhaps broader for many of the Terminalia species not traditionally used in Ayurveda due to the lack of even the most basic studies into their therapeutic potential and phytochemistry. Some interesting bioactivity studies have begun to be reported, examining African and South American 
Terminalia species in recent years. However, most of the tested species have still only been tested for 1 or 2 medicinal properties and these studies are usually driven purely by an ethnobotanical history of use. Given the taxonomic similarities between species of this genus, it is evident that more bioactivity studies are needed, and where a therapeutic bioactivity is detected, phytochemical and mechanistic studies are also required. Similarly, Australian Terminalia species have been poorly studied despite an oral history of medicinal usage. Since several recent studies have reported on the extremely high antioxidant content of $T$. ferdinandiana, there has been recent interest in this species. However, these studies have generally only focussed on bioactivity screening or phytochemical screening, without combining these disciplines for a bioactivity driven approach to characterising the active components and mechanisms. Whilst T. ferdinandiana is receiving recent attention, the other Australian species remain largely unstudied and substantial work is needed in this area.

At present, the Terminalia species tested are generally only those with a history of use in traditional medicinal systems. Yet, the similarity between many species indicates that testing all species for bioactivities evident in the more established species is warranted. Much investigation is required for a more complete understanding, not only of the potential of plants from this genus, but also to understand their phytochemistry. Such an approach will definitely lead to the establishment of useful nutraceuticals, but may also result in the development of further pharmaceuticals.

\section{REFERENCES}

Adentunji VO, Salawu OT. Efficacy of ethanolic leaf extracts of Carica papaya and Terminalia catappa as molluscicides against the snail intermediate hosts of schistosomiasis. Journal of Medicinal Plants Research 2010; 4 (22): 2348-2352.

Agarwal S, Kulkarni GT, Sharma VN. A comparative study on the antioxidant activity of methanolic extracts of Terminalia paniculata and Madhuca longifolia. Free Radicals and Antioxidants 2011; 1 (4): 62-68.

Agbedahunsi JM, Anao I, Adewunmi CO, Croft SL. Trypanocidal properties of Terminalia ivorensis A. Chev (Combretaceae). African Journal of Complementary and Alternative Medicines 2006; 3 (2): 51-56. 
Ahmed SM, BM VS, Dhanapal GR, Chandrashekara VM. Anti-diabetic activity of Terminalia catappa Linn. Leaf extracts in Alloxan-induced diabetic rats. Iranian Journal of Pharmacology and Therapeutics 2005; 4 (1): 36-39.

Ahsan H, Hadi SM. Strand Scission in DNA induced by curcumin in the presence of Cu(II), Cancer Letters 1998; 124: 23-30.

Aimola A, Inuwa HM, Mamman AI, Habila N, Agbaji AS, Omoniwa D. Terminalia catappa extract enhances erythropoiesis in adult Balb C mice. Journal of Molecular Biology Research 2011; 1 (1): 40-46.

Akinyemi KO, Oladapo O, Okwara CE, Ibe CC, Fasure KA. Screening of crude extracts of six medicinal plants used in South-West Nigerian unorthodox medicine for anti-methicillin resistant Staphylococcus aureus activity. BMC Complementary and Alternative Medicine 2005; 5: 6.

Alayande LB, Alayande MO, Mohammed AA, Adamu T, Abubakar U, Daneji A, Ajagbonna OP. Efficacy of Terminalia avicennoides and its combination with diminazene aceturate (Berenil ${ }^{\circledR}$ ) in rats experimentally infected with Trypanosoma brucei brucei. Sokoto Journal of Veterinary Sciences 2011; 9 (2): 11-15.

Ali A, Kaur G, Hayat K, Ali M, Ather M. A novel naphthanolglycoside from Terminalia arjuna with antioxidant and nitric oxide inhibitory activities. Pharmazie 2003a; 58: 932-934.

Ali A, Kaur G, Hamid H, Abdulla T, Ali M, Niwa M, Alam MS. Terminoside A, a newtriterpine glycoside from the bark of Terminalia arjuna inhibits nitric oxide production in murine macrophages. Journal of Asian Natural Product Research 2003b; 5: 137-142.

Aliyu ZY, Gordeuk V, Sachdev V, Babadoko A, Mamman AI, Akpanpe P, Attah E, Suleiman Y, Aliyu N, Yusuf J et al. Prevalence and risk factors for pulmonary artery 
systolic hypertension among sickle cell disease patients in Nigeria. American Journal of Hematology 2008; 83, 485-490.

Anam K, Suganda AG, Sukandar EY, Broto L, Kardono S. Antibacterial effect of component of Terminalia muelleri Benth against Staphylococcus aureus. International Journal of Pharmacology 2010; 6 (4): 369-374.

Aneja KR, Joshi R. Evaluation of antimicrobial properties of fruit extracts of Terminalia chebula against dental caries pathogens. Jundishapur Journal of Microbiology 2009; 2 (3): 105-111.

Aneja KR, Sharma C, Joshi R. Antimicrobial activity of Terminalia arjuna Wight \& Arn: An ethnomedicinal plant against pathogens causing ear infection. Brazilian Journal of Otorhinolaryngology 2012; 78 (1): 68-74.

Anjaneyulu ASR, Prasad AVR. Chemical examination of roots of Terminalia arjuna (Roxb.) Wight \& Arnot. Part I. Characterisation of two new triterpenoid glycosides. Indian Journal of Chemistry 1982a; 21B: 530-533.

Anjaneyulu ASR. Prasad AVR. Chemical examination of roots of Terminalia arjuna-the structure of arjunoside III and arjunoside IV, two new triterpenoid glycosides. Phytochemistry 1982b; 21: 2057-2060.

Anjaneyulu ASR, Prasad AVR. Structure of terminic acid, a dihydroxy triterpene carboxylic acid from Terminalia arjuna. Phytochemistry 1983; 22: 993-998.

Araya-Maturana R, Heredia-Moya J, Donoso-Tauda O, Vera M, Toledo Hernández J, Pavani M, Pessoa-Mahana H, Weiss-López B, Ferreira J. 2008, Effects of simple and angular chromones on tumor cell respiration. Natural Products Communications 2008; 3 (4): 519-525.

Astaneie F, Afshari M, Mojtahedi A, Mostafalou S, Zamani MJ, Larijani B, Abdollah M. Total antioxidant capacity and levels of epidermal growth factor and nitric oxide 
in blood and saliva of insulin-dependent diabetic patients. Archives of Medical Research 2005; 36 (4): 376-81.

Awad AB, Toczek J, Carol CS, Fink S. Phytosterols decrease prostaglandin release in cultured $\mathrm{P} 388 \mathrm{D}_{1} / \mathrm{MAB}$ macrophages, Prostaglandins, Leukotrienes and Essential Fatty Acids 2004; 70 (6): 511-520.

Baker A, Payne CM, Briehl MM, Powis G. Thioredoxin, a gene found overexpressed in human cancer, inhibits apoptosis in vitro and in vivo, Cancer Research 1997; 57: 5162-5167.

Baliga MS. Triphala, Ayurvedic formulation for treating and preventing cancer: A review. The Journal of Alternative and Complementary Medicine 2010; 16 (12): 1301-1308.

Balleisen l, Gay S, Marx R, Kuhn K. Comparative investigation of the influence of human and bovine collagen types I, II and III on the aggregation of human platelets. Wein Klin Wechenschr 1975; 53: 903-905.

Betterle C, Zanette F, Pedini B, Presotto F, Rapp LB,Monciotti CM, Rigon F. Clinical and subclinical organ-specific autoimmune manifestations in type I (insulindependent) diabetic patients and their first-degree relatives. Diabetologia 1984; 26: 431-436.

Bhatia J, Bhattacharya SK, Mahajan P, Dwivedi S. Effect of Terminalia arjuna on coronary flow-an experimental study (Abstract). Indian Journal of Pharmacology 1998; 30: 118.

Biswas M, Biswas K, Karan TK, Bhattacharya S, Ghosh AK, Haldar PK. Evaluation of analgesic and anti-inflammatory activities of Terminalia arjuna leaf. Journal of Phytology 2011; 3 (1): 33-38. 
Brown NS, Bicknell R. 2001, Hypoxia and oxidative stress in breast cancer. Oxidative stress: its effects on the growth, metastatic potentialand response to therapy of breast cancer, Breast Cancer Research 2001; 3: 323-327.

Carluccio MA, Sicuella L, Ancora MA, Massaro M, Scoditti E, Storelli C, Visioli F, Distante A De Caterina R. Olive oil and red wine antioxidant polyphenols inhibit endothelial activation: antiatherogenic properties of Mediterranean diet phytochemicals. Arteriosclerosis, Thrombosis and Vascular Biology 2003; 23: 622629.

Chang CL, Lin CS. Phytochemical composition, antioxidant activity, and neuroprotective effect of Terminalia chebula Retzius extracts. Evidence Based Complementary and Alternative Medicine 2012; article ID 125247.

Chattopadhyay RR, Battacharyya SK. Plant review: terminalia chebula: An update. Pharmacognosy Reviews 2007; 1 (1): 151-156.

Chaudhari M, Mengi S. Evaluation of phytoconstituents of Terminalia arjuna for wound healing activity in rats. Phytotherapy Research 2006; 20: 799-805.

Cheng HY, Lin CC, Lin TC. 2002. Antiherpes simplex virus type 2 activity of casuarinin from the bark of Terminalia arjuna Linn. Antiviral Research 55: 447-455.

Cherikoff V, Kowalski G. Superfoods for Superhealth. Discover the Wonders of Australian Native Fruits. 2008 [Last cited on 2010 Oct 07]. Available from: http://www.kakadujuice.com/clientinc/upload/Promotional.Tools/SuperFoods\%20Exc erpt.pdf.

Chitsulo L, Engels D, Montresor A, Savioli L. The global status of schistosomiasis and its control. Acta Tropica 2000; 77: 41-51. 
Choi S, Chung $\mathrm{MH}, 2003$, A review on the relationship between Aloe vera components and their biological effects. Seminars In Integrative Medicine, 1, 1, 5362.

Choi SW, Son BW, Son YI, Park YI, Lee SK, Chung MH. The wound-healing effect of a glycoprotein fraction isolated from aloe vera. British Journal of Dermatology 2001; 145 (4): 535-554.

Chopra RN, Nayar SL, Chopra IC. Glossary of Indian Medicinal Plants. New Delhi, CSIR, 1956.

Cock IE. Problems of reproducibility and efficacy of bioassays using crude extracts, with reference to Aloe vera. Pharmacognosy Communications 2011; 1 (1): 52-62.

Cock IE. The early stages of rheumatoid arthritis: New targets for the development of combinational therapies. OA Arthritis 2014; 2(1):5.

Cock IE. Medicinal and aromatic plants - Australia, in Ethnopharmacology section, Biological, Physiological and Health Sciences, Encyclopedia of Life Support Systems (EOLSS), 2011; Developed under the Auspices of the UNESCO, EOLSS Publishers, Oxford ,UK, (http://www.eolss.net).

Cock IE, Mohanty S. Evaluation of the antibacterial activity and toxicity of Terminalia ferdinandia fruit extracts. Pharmacognosy Journal 2011; 3 (20): 72-79.

Cock IE, van Vuuren SF. A comparison of the antimicrobial activity and toxicity of six Combretum and two Terminalia species from Southern Africa. Pharmacognosy Magazine 2015a; 11(41): 208-218. DOI: 10.4103/0973-1296.149740

Cock IE, van Vuuren SF. South African food and medicinal plant extracts as potential antimicrobial food agents. Journal of Food Science and Technology 2015b; DOI 10.1007/s13197-015-1806-3 
Cock IE, van Vuuren SF. The potential of selected South African plants with antiKlebsiella activity for the treatment and prevention of ankylosing spondylitis. Inflammopharmacology 2015; 23: 21-35. DOI: 10.1007/s10787-014-0222-z

Cock IE, van Vuuren SF. Anti-Proteus activity of some South African medicinal plants: Their potential for the prevention of rheumatoid arthritis. Inflammopharmacology 2014; 22: 23-36. DOI: 10.1007/s10787-013-0179-3

Corner EJH. Wayside Trees of Malaya. 4th Edn, Malayan Nature Society 1997; 1: 217.

Courtney R, Sirdaarta J, Matthews B, Cock IE. Tannin components and inhibitory activity of Kakadu plum leaf extracts against microbial triggers of autoimmune inflammatory diseases. Pharmacognosy Journjal 2015; 7(1): 18-31. DOI: 10.5530/pj.2015.7.2

Cover C, Mansouni A. Peroxinitrate induced mitochondrial and endonuclease mediated nuclear DNA damage in acetaminophen hepatotoxicity. Journal of Pharmacology and Experimental Therapeutics 2005; 315: 879-887.

Crouch R, Kimsey G, Priest DG, Sarda A, Buse MG. Effect of streptozotocin on erythrocyte and retinal superoxide dismutase. Diabetologia 1978; 15: 53-57.

Cunningham AB, Garnett S, Gorman J, Courtenay K, Boehme D. Eco-Enterprises and Terminalia ferdinandiana: "Best Laid Plans” and Australian Policy Lessons. Econ Bot 2009;63:16-28.

Das B. Materia Medica of Ayurveda. New Delhi, Jain Publishers, 1991; 8.

Das ND, Jung KH, Park JH, Choi MR, Lee HT, Kim MS, Lee SR, Chai YG. Proteomic analysis of Terminalia chebula extract-dependent changes in human 
lymphoblastic T cell protein expression. Journal of Medicinal Food 2012; 15 (7): 651657.

Davi G, Ciabattoni G, Consoli A, Mezzetti A, Falco A, Santarone S, Pennese E, Vitacolonna E, Bucciarelli T, Constantini F, Capani F, Patrono C. 1999, In vivo formation of 8-iso-prostaglandin F2a and platelet activation in diabetes mellitus: effects of improved metabolic control and vitamin E supplementation. Circulation 1999; 99: 224-9.

Davis RH, Kabbani JM, Maro NP. Aloe vera and wound healing. Journal of the American Podiatric Medical Association 1987; 77: 165-169.

Davis W, Ze'ev Ronai JR, Tew KD. Cellular thiols and reactive oxygen species in drug-induced apoptosis. The Journal of Pharmacology and Experimental Therapeutics 2001; 296: 1, 1-5.

Dhetchuvi M, Lejoly J. Contribution a' la connaissance ds plantes me'dicinales du Nord- Est du Zaire. Mitt Inst Allg Bot Hamburg 1990; 23b: 991-1006.

Dongmo AB, Beppe, JG, Nole T, Kamanyi A. Analgesic activities of the stem bark extract of Terminalia superba Engl. Et Diels (Combreaaceae). Pharmacologyonline 2006; 171-177.

Dwivedi S. Terminalia arjuna Wright \& Arn. - A useful drug for cardiovascular disorders. Journal of Ethnopharmacology 2007; 114: 114-129.

Dwivedi S, Chansouria JPN, Somani PN, Udupa KN. Influence of certain indigenous drugs on the PGE like activity in the ischaemic rabbit aorta. Indian Drugs 1987; 2: 378-382.

Dwivedi S, Udupa N. Terminalia arjuna: pharmacognosy, phytochemistry, pharmacology and clinical use. A review. Fitoterpia 1989; 60: 413-420. 
Eesha BR, Mohanbabu AV, Meena KK, Sarath B, Vijay M, Lalit M, Rajput R. Hepatoprotective activity of Terminalia paniculata against paracetemol induced hepatocellular damage in Wistar albino rats. Asian Pacific Journal of Tropical Medicine 2011; 446-469.

Emanuel R, Farber JC. Repair, regeneration and fibrosis. In Pathology 1988; JB Lippincott Company: Philadelphia; 77-89.

Freemerman AJ, Powis G. A redox-inactive thioredoxin reduces growth and enhances apoiptosis in WEHI7.2 cells. Biochemical and Biophysical Research Communications 2000; 274: 136-141.

Fuhrman B, Aviram M. Antiatherogenecity of nutritional compounds. The Investigational Drug Journal 2001; 4: 82-92.

Fyhrquist P, Mwasumbi L, Haeggstrom CA, Vuorela H, Hiltunen R, Vuorela P. Ethnobotanical and antimicrobial investigation on some species of Terminalia and Combretum (Combretaceae) growing in Tanzania. Journal of Ethnopharmacology 2002; 79: 169-177.

Gauthaman K, Maulik M, Kumari R, Manchanda SC, Dinda AK, Maulik SK. Effect of chronic treatment with bark of Terminalia arjuna: a study on the isolated ischemicreperfused rat heart. Journal of Ethnopharmacology 2001; 75: 197-201.

Gill LS, Akinwunmi C. Nigerian Medicine Practice and Beliefs of the Ondo People. Journal of Ethnopharmacology 1986; 18: 257-266.

Gomes A, Neuwirth O, Freitas M, Couto D, Ribeiro D, Figueiredo AGPR, Silva AMS, Seixas RSGR, Pinto DCGA, Tomé AC, Cavaleiro JAS, Fernandes E, Lima JLFC. Synthesis and antioxidant properties of new chromone derivatives. Bioorganic and Medicinal Chemistry 2009; 17 (20): 7218-7226.

Grover IS, Bala S. Antimutagenic activity of T. chebula (myroblan) in Salmonella typhimurium. Indian Journal of Experimental Biology 1992; 30 (4): 339-341. 
Halliwell B. Vitamin C: Antioxidant or pro-oxidant in vivo?, Free Radical Research 1996; 25: 439-454.

Hamilos DL, Zelarney, P, Mascali JJ. Lymphocyte proliferation in glutathionedepleted lymphocytes: direct relationship between glutathione availability and the proliferative response. Immunopharmacology 1989; 18: 223-235.

Hanahan D, Weinberg RA, 2000, The hallmarks of cancer, Cell, 100, 1, 57-70.

Hazra B, Sarkar R, Biswas S, Mandal N. Comparative study of the antioxidant and reactive oxygen species scavenging properties in the extracts of the fruits of Terminalia chebula, Terminalia belerica and Emblica officinalis. BMC Complementary and Alternative Medicine 2010; 10: 20.

Herbert V, Shaw S, Jayatileke E. Vitamin C driven free radicals generation from iron. Journal of Nutrition 1996; 126: 1213-1220.

Hertog MG, Bueno-de-Mesquita HB, Fehily AM, Sweetnam PM, Elwood PC, Kromhout D. Fruit and vegetable consumption and cancer mortality in the caerphilly study. Cancer Epidemiology, Biomarkers and Prevention 1996; 5: 673-7.

Ishihara M, Sakagami H. Application of semiempirical method to estimate the cytotoxic activity of gallic acid and its related compounds. Anticancer Research 2003; 23: 2549-2552.

Jain S, Yadav PP, Gill V, Vasudeva N, Singla N. Terminalia arjuna a sacred medicinal plant; phytochemical and pharmacological profile. Phytochemistry Reviews 2009; 8(2): 491-502.

Jaiwal BV, Shaikh FK, Waghire HB, Sarwade BP. Comparative anti-oxidative potential of barks phenolics of genus Terminalia. International Journal of Science and Pharma Educational Research 2012; 1 (4): 6-10. 
Joel LS. The dual roles of nutrients as antioxidants and pro-oxidants: Their effects of tumor cell growth. In proceeding of the "Prooxidant Effects of Antioxidant Vitamins" experimental biology meeting, Atlanta, GA, Edited by Herbert V, American Society of Nutrition 1995; Bethesda, MD: 1221-1226.

Johnson PD. Acerola (Malpighia glabra L., M. punicifolia L., M. emarginata D.C.): agriculture, production and nutrition. World Rev Nutr Diet 2003;91:67-75.

Jueschke H, Knight TR. The role of oxidant stress and species in acetaminophen hepatotoxicity. Toxicology Letters 2003; 144: 279-288.

Kamboj VP, 2000, Herbal medicine. Current Science, 78, 35-39.

Kankri E, Vaali K, Knowles RG, Lahde M, Korppela R, Vapaatalo H, Moilanen E. Suppression of acute experimental colitis by a highly selective inducible nitric-oxide synthase inhibitor, N-[3-(aminomethyl)benzyl] acetamidine. Journal of Pharmacology and Experimental Therapeutics 2001; 298: 1128-1132.

Kannan M, Dasari A, Karthikeyan M, Ashokkumar J, Rajasekar S. Effect of Terminalia bellerica fruit Roxb on Alloxan induced diabetic related atherosclerosis on Wistar albino rats. International Journal of Phytopharmacology 2012; 3 (1): 5-9.

Karalliedde L, Gawarammana I. Traditional Herbal Medicines. A Guide To Their Safe Use, Shaw D, ed, Hammersmith Press Ltd 2008; London, UK.

Kasabri V, Flatt PR, Abdel-Wahab YHA. Terminalia bellerica stimulates the secretion and action of insulin and inhibits starch digestion and protein glycation in vitro. British Journal of Nutrition 2010; 103: 212-217.

Kaur S, Michael H, Arora S, Härkönen PL, Kumar S. The in vitro cytotoxic and apoptotic activity of Triphala: An Indian herbal drug. Journal of Ethnopharmacology 2005; 97: 15-20. 
Khanna AK, Chander C, Kapoor NK. Terminalia arjuna: an Ayurvedic cardiotonic regulates lipid metabolism in hyperlipidemic rats. Phytotherapy Research 1996; 10: $663-665$.

Kim HS, Lee JH, Kim IK. Intracellular glutathione level modulates the induction of apoptosis by delta 12-prostaglandin J2. Prostaglandins 1996; 51: 413-425.

Klein R. Hyperglycemia and microvascular and macrovascular disease in diabetes. Diabetes Care 1995: 18: 258-268.

Konczak I, Zabaras D, Dunstan M, Aguas. Antioxidant capacity and hydrophilic phytochemicals in commercially grown Australian fruits. Food Chem 2010;123:104854.

Kumar GPS, Arulselvan P, Kumar DS, Subramanian SP. Anti-diabetic activity of fruits of Terminalia chebula streptozotocin induced diabetic rats. Journal of Health Science 2006; 52 (3): 283-291.

Kuo PL, Hsu YL, Lin TC, Chang JK, Lin CC. Induction of cell cycle arrest and apoptosis in human non-small cell lung cancer A549 cells by casuarinin from the bark of Terminalia arjuna Linn. Anti-Cancer Drugs 2005; 16 (4): 409-415.

Lassak EV, McCarthy T. Australian medicinal plants. New Holland Publishers 2006; Australia.

Lastra CA, Villegas I. Resveratrol as an antioxidant and pro-oxidant agent: Mechanisms and clinical implications, Biochemical Society Transactions 2007; 35: 1156-1160.

Lee KY, Park JH, Chung MH, Park YI, Kim KW, Lee YJ, Lee SK. Aloesin upregulates cyclin E/CDK2 kinase activity via inducing the protein levels of cyclin E, CDK2, and CDC25A in SK-HEP-1 cells. IUBMB Life 1997; 41 (2): 285-292. 
Li K, Diao Y, Zhang H, Wang S, Zhang Z, Yu B, Huang S, Yang H. Tannin extracts from immature fruits of Terminalia chebula Fructus Retz. Promote cutaneous wound healing in rats. BMN Complimentary and Alternative Medicine 2011; 11: 86.

Lin LT, Chen TY, Chung CY, Noyce RS, Grindley TB, McCormick C, Lin TC, Wang GH, Lin CC, Richardson CD. Hydrolyzable tannins (chebulagic acid and punicalagin) target viral glycoprotein-glycosaminoglycan interactions to inhibit herpes simplex virus 1 entry and cell-to-cell spread. Journal of Virology 2011; 85 (9): 4386-4398.

Lin TC, Chien SC, Chen HF, Hsu FL. Tannins and related compounds from Combretaceae plants. Chinese Pharmaceutical Journal 2001; 52: 1-26.

Lin SZ, Tong HF, Chen KG, Jing H, Yang X, Zheng SS, 2010, Effect of emodin in suppressing acute rejection following liver allograft transplantation in rats, Chinese Journal of Integrative Medicine, 16, 2, 151-156.

Losso JN, Bansode RR, Trappey A, Bawadi HA, Truax R. In vitro anti-proliferative activities of ellagic acid. J Nutr Biochem 2004;15:672-78.

Makino Y, Yoshikawa N, Okamoto K, Hirota K, Yodoi J, Makino I, Tanaka H. Direct association with thioredoxin allows redox regulation of glucocorticoid receptor function. Journal of Biological Chemistry 1999; 274: 3182-3188.

Manna P, Sinha M, Sil PC. Aqueous extract of Terminalia arjuna prevents carbon tetrachloride induced hepatic and renal disorders. BMC Complenentary and Alternative Medicine; 6: 33.

Macpherson G. Inflammation. Blacks Medical Dictionary 1992; A and C Black, London, UK.

Maregesi S, Van Miert S, Pannecouque C, Feiz Haddad MH, Hermans N, Wright CW, Vlietinck AJ, Apers S, Pieters L. Screening of Tanzanian medicinal plants against Plasmodium falciparum and human immunodeficiency virus. Planta Medica 2010; 76: 195-201. 
Martikainen JA, Ottelin AM, Kiviniemi V, Gylling H. Plant stanol esters are potentially cost-effective in the prevention of coronary heart disease in men: Bayesian modelling approach. European Journal of Cardiovascular Prevention and Rehabilitation 2007; 14: 265-272.

Martino VS, López P, Martinez Irujo JJ, Sanromán M, Cuevas MT, Santiago E, Lasarte JJ, Font M, Coussio JD, Mongue A. Inhibitory effect against polymerase and ribonuclease activities of HIV-reverse transcriptase of the aqueous leaf extract of Terminalia triflora. Phytotherapy Research 2002; 16: 778-780.

Masoka P, Eloff JN. Screening of twenty-four South African Combretum and six Terminalia species (Combretaceae) for antioxidant activities. African Journal of Traditional Complementary and Alternative Medicine 2007; 4 (2): 231-239.

Masoka P, Eloff JN. The diversity of antifungal compounds of six South African Terminalia species (Combretaceae) determined by bioautography. African Journal of Biotechnology 2005; 4 (12): 1425-1431.

Mbwambo ZH, Erasto P, Nondo RO, Innocent E, Kidukuli AW. Antibacterial and cytotoxic activities of Terminalia stenostachya and Terminalia spinosa. Tanzania Journal of Health Research 2011; 13 (2): 1-8.

McGaw LJ, Rabe T, Sparg SG, Jäger AK, Ejoff JN, van Staden J. An investigation on the biological activity of Combretum species. Journal of Ethnopharmacology 2001; 75: 45-50.

Mety SS, Mathad P. Antioxidative and free radical scavenging activities of Terminalia species. International Journal of Biotechnology 2011; 2 (5): 119-127.

Mgbemene CN, Ohiri FC. Anti-sickling potential of Terminalia catappa leaf extract. Pharmaceutical biology 1999; 37(2): 152-154. 
Middleton E, Kandaswami C, Theorharides TC. The effect of plant flavonoids on mammalial cells: inflammation, heart disease and cancer. Pharmacological Review 2000; 52: 673-751.

Miller JB, James KW, Maggiore PM. Tables of composition of Australian Aboriginal foods. Aboriginal Studies Press, 1993; 256.

Mochizuki M, Hasegawa N. Anti-inflammatory effect of extract of Terminalia sericea roots in an experimental model of colitis. Journal of Health Science 2007; 53 (3): 329331.

Mohanty S, Cock IE. The chemotherapeutic potential of Terminalia ferdinandiana: Phytochemistry and bioactivity. Pharmacognosy Reviews 2012; 6 (11): 29-36.

Momo CEN, Ngwa AF, Dongmo IF, Oben JE. Antioxidant properties and $\alpha$-amylase inhibition of Terminalia superba, Albizia sp., Cola nitida, Cola odorata and Harungana madagascarensis used in the management of diabetes in Cameroon. Journal of Health Science 2009; 55 (5): 732-738.

Moon EJ, Lee YM, Lee OH, Lee MJ, Lee SK, Chung MH, Park YI, Sung CK, Choi JS, Kim KW. A novel angiogenic factor derived from Aloe vera gel: b-sitosterol, a plant sterol. Angiogenesis 1999; 3: 117-123.

Moshi MJ, Mbwambo ZH. Some pharmacological properties of extracts of Terminalia sericea roots. Journal of Ethnopharmacology 2005; 97: 43-47.

Moskaug JO, Carlsen H, Myhrstad MC, Blomhoff R. Polyphenols and glutathione synthesis regulation. Am J Clin Nutr 2005;81:277-83S.

Mudi SY, Muhammad A. Antimalaria activity of ethanolic extracts of leaves of Terminalia catappa L. Combretaceae (Indian almond). Bayero Journal of Pure and Applied Sciences 2009; 2 (1): 14-18. 
Nadkarni AK. Terminalia chebula. In: Dr. K.M. Nadkarni’s Indian Materia Madica, 3rd ed., Bombay, Popular Prakashan Pvt. Ltd., 1976; 1202-11.

Nair S, Nagar R. Antioxidant flavonoids in common Indian foods. South Asian Journal of Preventive Cardiology 1997; 1: 33-35.

Nair S, Nair R, Gupta R. Dietary antioxidant, phenolics and flavonoids in coronary heart disease (Abstract). Indian Heart Journal 1996; 48: 545.

Nammi S, Gudavalli R, Ravindra Babu BS, Lodagala DS, Boini KM. Possible mechanisms of hypotension produced $70 \%$ alcoholic extract of Terminalia arjuna (L.) in anaesthetized dogs. BMC Complementary and Alternative Medicine 2003; 3: 5.

Netzel M, Netzel G, Tian Q, Schwartz S, Konczak I. Native Australian fruits - a novel source of antioxidants for food. Innov Food Sci Emerg Technol 2007;8:339-46.

Newman DJ, Cragg GM, 2007, Natural products as sources of new drugs over the last 25 years, Journal of Natural Products, 70, 3, 461-477.

Nagappa AN, Thakurdesai PA, Rao NV, Singh J. Antidiabetic activity of Terminalia catappa Linn fruits. Journal of Ethnopharmacology 2003; 88: 45-50.

Njomem GBSN, Kamgang R, Soua PRN, Oyono JLE, Njikam N. Protective effect of methanol-methylene chloride extract of Terminalia glaucescens leaves on streptozotocin-induced diabetes in mice. Tropical Journal of Pharmaceutical Research 2009; 8 (1): 19-26.

Nkoble NK. Antidiabetic activity of pentacyclic triterpenes and flavonoids isolated from stem bark of Terminalia sericea Burch. Ex DC. Masters thesis 2009; dept Plant Science: University of Pretoria.

Ohno Y, Fukuda K, Takemura G, Toyota M, Watanabe M, Yasuda N, et al. Induction of apoptosis by gallic acid in lung cancer cells. Anticancer Drugs 1999;10:845-51. 
Okamoto K, Tanaka H, Ogawa H, Makino Y, Eguchi H, Hayashi S, Yoshikawa N, Poellinger L, Umesono K, Makino I. Redox-dependent regulation of nuclear import of the glucocorticoid receptor, Journal of Biological Chemistry 1999; 274: 1036310371.

Peluso MR. Flavonoids attenuate cardiovascular disease, inhibit phosphodiesterase and modulate lipid homeostasis in adipose tissue and liver. Experimental Biology Medicine (Maywood) 2006; 231: 1287-1299.

Penckofer S, Schwertz D, Florczak K. Oxidative stress and cardiovascular disease in type 2 diabetes: the role of antioxidants and prooxidants. Journal of Cardiovascular Nursing 2002; 16 (2): 68-85.

Pettit GR, Hoard MS, Doubek DL, Schmidt JM, Pettit RK, Tackett LP, Chapuis JC. Antineoplastic agents 338. The cancer cell growth inhibitory constituents of Terminalia arjuna (Combretaceae). Journal of Ethnopharmacology 1996; 53: 57-63.

Pinmai K, Chunlaratthanabhorn S, Ngamkitidechakul C, Soonthornchareon N, Hahnvajanawong C. Synergistic growth inhibitory effects of Phyllanthus emblica and Terminalia bellerica extracts with conventional cytotoxic agents: Doxorubicin and cisplatin against human hepatocellular carcinoma and lung cancer cells. World Journal of Gastroenterology 2008; 14 (10): 1491-1497.

Pinmai K, Hiriote W, Soonthornchareonnon N, Jongsakul K, Sireeratawong S, TorUdom S. In vitro and in vivo antiplasmoidal activity and cytotoxicity of water extracts of Phyllanthus emblica, Terminalia chebula and Terminalia bellerica. Journal of Medical Association of Thailand 2010; 93 (Suppl 7): S120-126.

Planes de Banchero E, Souto J, Actividad antivirica de algunas plantas indigenas. Rev Invest Agropec (INTA Buenos Aires) 1969; 6: 155-171.

Potter JD. Cancer prevention: Epidemiology and experiment. Cancer Letters 1997; 114: 7-9. 
Pyke DA. Genetics of diabetes. Journal of Clinical Endocrinology and Metabolism 1977; 6: 285-303.

Ragavan B, Kumari K. Effect of Terminalia arjuna stem bark extract on antioxidant status in liver and kidney of Alloxan diabetic rats. Indian Journal of Physiology and Pharmacology 2006; 50 (2): 133-142.

Rahimi R, Nikfar S, Larijani B, Abdollahi M. A review on the role of antioxidants in the management of diabetes and its complications. Biomedicine and Pharmacotherapy 2005; 59: 365-373.

Rahman A, Shahabuddin M, Hadi SM, Parish J. Complexes involving quercetin, DNA and Cu(II). Carcinogenesis 1990; 11: 2001-2003.

Rahman AU, Zareen S, Choudhary MI, Akhtar MN, Shujaat S, Ngounou FN. Some chemical constituents of Terminalia glaucescens and their enzyme inhibition activity. Zeitschrift für Naturforschung. B, Chemical Sciences, 2005; 60(2): 347-350.

Ramachandran S, Rajasekaran A, Manisenthilkumar KT. Investigation of hypoglycaemic, hydrolipidemic and antioxidant activities of aqueous extract of Terminalia paniculata bark in diabetic rats. Asian Pacific Journal of Tropical Biomedicine 2012; 262-268.

Rane MM, Mengi SA. Comparative effect of oral administration and topical application of alcoholic extract of Terminalia arjuna on experimental wounds in rats. Fitoterapia 2003; 74: 553-558.

Rao NK, Nammi S. Antidiabetic and renoprotective effects of the chloroform extract of Terminalia chebula Retz. Seeds in streptozotocin-induced diabetic rats. BMC Complementary and Alternative Medicine 2006; 6: 17.

Rao BK, Sudarshan PR, Rajasekhar MD, Nagaraju N, Rao CA. Antidiabetic activity of Terminalia pallida fruit in Alloxan induced diabetic rats. Journal of Ethnopharmacology 2003; 85: 169-172. 
Rayan P, Matthews B, McDonnell PA, Cock IE. Terminalia ferdinandiana extracts as inhibitors of Giardia duodenalis proliferation: a new treatment for giardiasis. Parasitology Research 2015; 114: 2611-2620. DOI: 10.1007/s00436-015-4465-4

Reddy DB, Reddanna P. Chebulagic acid (CA) attenuates LPS-induced inflammation by suppressing NK-KB and MAPK avtivation in RAW 264.7 macrophages. Biochemical and Biophysical Research Communications 2009; 381: 112-117.

Reddy DB, Reddy TC, Jyotsna G, et al.: Chebulagic acid, a COX-LOX dual inhibitor isolated from the fruits of Terminalia chebula Retz., induces apoptosis in COLO-205 cell line. Journal of Ethnopharmacology 2009;124: 506-512.

Rice-Evans C, Miller N, Paganga. Antioxidant properties of phenolic compound. Trends Plant Sci 1997;2:152-9.

Rivas M, Distefano A. Estudio de la acción antiviral de Terminalia triflora. Rev Asoc Argent Microbiol 1973; 5: 55-56.

Rivas M, Distefano A Graziano MN. Congreso Latinoamerico de Microbiologia. Punta del Este 1971; Abstract 21.

Robbins MJ, Sharp RA, Slonium AE, Burr IM. Protection against streptozotocininduced diabetes by superoxide dismutase. Diabetologia 1980; 18: 55-58.

Robertson RP, Chen M. A role for prostaglandin E in defective insulin secretion and carbohydrate intolerance in diabetes mellitus. Journal of Clinical Investigation 1977; 60: 747-753.

Rode T, Frauen M, Muller BW, Dusing HJ, Schonrock U, Mundt C, Wenck H. Complex formation of sericoside with hydrophilic cyclodextrins: improvement of solubility and skin penetration in topical emulsion based formulations. European Journal of Pharmaceitics and Biopharmaceutics 2003; 55: 191-198. 
Ruefli AA, Davis JE, Sutton VR, Trapani JA, Smyth MJ, Johnstone RW. Disecting the apoptopic mechanisms of chemotherapeutic drugs and lymphocytes to design effective anticancer therapies, Drug Development Research 2001; 52: 549-557.

Ruff JC. Wine and polyphenols related to platelet aggregation and atherothrombosis. Drugs under Experimental and Clinical Research 2003; 25: 125-131.

Sabu MC, Kuttan R. Antidiabetic and antioxidant activity of Terminalia belerica. Roxb. Indian Journal of Experimental Biology 2009; 47 (4): 270-275.

Saguna L, Singh S, Sivakumar P, Sampath P, Chandrakasan G. Influence of Terminalia chebula on dermal wound healing in rats. Phytotherapy Research 2002; 16: $227-231$.

Sakaguchi N, Inoue M, Isuzugawa K, Ogihara Y, Hosaka K. Cell death-inducing activity by gallic acid derivatives. Biological and Pharmaceutical Bulletin 1999; 22: 471-475.

Sandhya T, Mishra KP. Cytotoxic response of breast cancer cell lines, MCF-7 and T 47 D to triphala and its modification by antioxidants. Cancer Letters 2006; 238: 304 313.

Samuni A, Aronovitch J, Godinger D, Chevion M, Czapsk G. On the cytotoxicity of vitamin $\mathrm{C}$ and metal ions. A site-specific Fenton mechanism. European Journal of Biochemistry 1983; 137: 119-124.

Sandhya T, Lathika KM, Pandey BN, Mishra KP. Potential of traditional Ayurvedic formulation, triphala, as a novel anticancer drug. Cancer Letters 2006a; 231 :206-214.

Sandler S, Andersson A. The partial protective effect of the hydroxyl radical scavenger dimethyl urea on streptozotocin-induced diabetes in the mouse in vivo and in vitro. Diabetologia, 1982; 23: 374-378. 
Sasidharan I, Sundaresan A, Nisha VM, Kirishna MS, Raghu KG, Jayamurthy P. Inhibitory effect of Terminalia chebula Retz. Fruit extracts on digestive enzyme related to diabetes and oxidative stress. Journal of Enzyme Inhibition and Medicinal Chemistry 2012; Early online: 1-9.

Shaba P, Pandey NN, Sharma OP, Rao RJ, Singh RK. In vitro trypanocidal activity of comparative extraction of Terminalia bellirica (Combretaceae) dried fruits with solvents of different polarities against Trypanosma evansi. The Internet Journal of Veterinary Medicine 2009a; 6 (1).

Shaba P, Pandey NN, Sharma OP, Rao RJ, Singh RK. Therapeutic evaluation of Terminalia bellirica (Combretaceae) dried fruits against Trypanosma evansi. The Internet Journal of Veterinary Medicine 2009b; 7 (1).

Shaila HP, Udupa SL, Udupa AL. Hypolipidemic activity of three indigenous drugs in experimentally induced atherosclerosis. International Journal of Cardiology 1998; 67: $119-124$.

Sharma PN, Shoeb PN, Kapil RS, Popli SP. Arjunolone-a new flavone from stem bark of Terminalia arjuna. Indian Journal of Chemistry 1982; 21B: 263-264.

Shi Y, Sahu RP, Srivastava SK. Triphala inhibits both in vitro and in vivo xenograft growth of pancreatic tumor cells by inducing apoptosis. BMC Cancer 2008; 8: 294.

Shih CC, Wu YW, Lin WC. Antihyperglycemic and antioxidant properties of Anoectochilus Formosanus in diabetic rats. Clinical and Experimental Pharmacology and Physiology 2002; 29: 684-688.

Shinde SL, Junne SB, Wadje SS, Baig MMV. The diversity of antibacterial compounds of Terminalia species (Combretaceae). Pakistan Journal of Biological Sciences 2009; 12 (22): 1483-1486.

Simons SS, Pratt WB. Glucocorticoid receptor thiols and steroid-binding activity. Methods in Enzymology 1995; 251: 406-422. 
Singh S, Farhan AS, Ahmad A, Khan NU, Hadi SM, 2001a, Oxidative DNA damage by capsaicin and dihydrocapsaicin in the presence of $\mathrm{Cu}(\mathrm{II})$, Cancer Letters, 169, 139146.

Singh R, Barden A, Mori, T, Beilin L. Advanced glycation end-products: a review. Diabetologia 2001b; 44: 129-146.

Sirdaarta J, Matthews B, Cock IE. Kakadu plum fruit extracts inhibit growth of the bacterial triggers of rheumatoid arthritis: Identification of stilbene and tannin components. Journal of Functional Foods 2015a; 17: 610-620. DOI: 10.1016/j.jff.2015.06.019

Sirdaarta J, Matthews B, White A, Cock IE. GC-MS and LC-MS analysis of Kakadu plum fruit extracts displaying inhibitory activity against microbial triggers of multiple sclerosis. Pharmacognosy Communications 2015b; 5(2): 100-115. DOI: 10.5530/pc.2015.2.2

Sivalokanathan S, Ilyaaraja M, Balasubramanian MP. Antioxidant activity of Terminalia arjuna bark extract on $N$-nitrosodiethylamine induced hepatocellular carcinoma in rats. Molecular and Cellular Biochemistry 2006; 281: 87-93.

Sumithira P, Dhivya Mangala S, Sophie AM, Padma Latha C. Antiviral and antioxidant activities of two medicinal plants. International Journal of Current Science 2012; 256-261.

Tager H. Abnormal products of human insulin gene. Diabetes 1984; 33: 693-699.

Takahashi S, Tanaka H, Hano Y, Ito K, Nomura T, Shigenobu K. Hypotensive effects in rats of hydrophyllic extract from Terminalia arjuna containing tannin-related compounds. Phytotherapy Research 1997; 1: 424-427. 
Tandon S, Rastogi R, Kapoor NK. Protection by abana, a herbomineral preparation, against myocardial necrosis in rats induced by isoproterenol. Phytotherapy Research 1995; 9: 263-266.

Tome ME, Baker AF, Powis G, Payne CM, Briehl MM, 2001, Catalaseoverexpressing thymocytes are resistant to glucocorticoid-induced apoptosis and exhibit increased net tumor growth, Cancer Research, 61, 2766-2773.

Tripathi VK, Singh B. Terminalia arjuna- its present status (a review). Oriental Journal of Chemistry 1996; 12(1): 1-16.

Tsuda T, Horio F, Uchida K, Aoki H, Osawa T. Dietary cyaniding 3-O-b- Dglucoside-rich purple corn colour prevents obesity and ameliorates hyperglycemia in mice. J. Nutr 2003;133:2125-30.

Udupa KN. Scope of use of Terminalia arjuna in ischaemic heart disease. Annals of the National Academy of Indian Medicine 1986; 1: 54.

Vessby J, Basu S, Mohsen R, Berne C, Vessby B. Oxidative stress and antioxidant status in type 1 diabetes mellitus. Journal Internal Medicine 2002; 251: 69-76.

Vita JA. Polyphenols and cardiovascular disease: Effects on endothelial and platelet function. Am J Clin Nutr 2005;81:292S- 7S.

Vivancos M, Moreno JJ. $\beta$-Sitosterol modulates antioxidant enzyme response in RAW 264.7 macrophages. Free Radical Biology and Medicine 2005; 39 (1): 91-97.

Walsh G, 2003, Biopharmaceuticals: Biochemistry and Biotechnology, 3rd ed. Wiley, Chinchester.

Wilma DSC, Kavya N, Kulkarni S. Evaluation of insulin sensitivity status in polycystic ovarian syndrome. Asian Pacific Journal of Tropical Disease 2011; 1(1): 67-70. 
Woods B. A study of the intra-specific variations and commercial potenatial of Terminalia fredinandiana (the kakadu Plum). MSc thesis, Northern Territory University, Australia, 1995.

Wu CC, Lu YH, Wei BL, Yang SC, Won SJ, Lin CN. Phloroglucinols with prooxidant activity from Garcinia subelliptica. Journal of Natural Products 2008; 71: 246-250.

Yagi A, Kabash A, Okamura N, Haraguchi H, Moustafa SM, Khalifa TI. 2002, Antioxidant, free radical scavenging and anti-inflammatory effects of aloesin derivatives in Aloe vera. Planta Medica 2002; 68 (11): 957-960.

Yoon JW, Austin M, Onodera T, Notkins AC. Virus induced diabetes mellitus: isolation of a virus from the pancreas of a child with diabetic ketoacidosis. New England Journal of Medicine 1979; 300: 1173-1179.

Youdim KA, Spencer JP, Schroeter H, Rice-Evans CA. Dietary flavonoids as potential neuroprotectans. Biol Chem 2002;383:503-19. 
Figure 1: Chemical structures of molecules with antioxidant potential identified in T. ferdinandiana: (a) ascorbic acid (vitamin C), (b) gallic acid, (c) ellagic acid, (d) $\alpha$-tocopherol (vitamin E), (e) chlorophyll a, (f) chlorophyll b, (g) lutein, (h) hesperitin, (i) kaempferol, (j) luteolin, (k) quercetin.

a

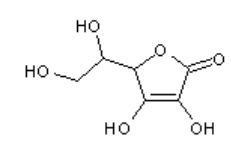

b<smiles>O=Cc1cc(O)c(O)c(O)c1</smiles>

c<smiles></smiles>

d

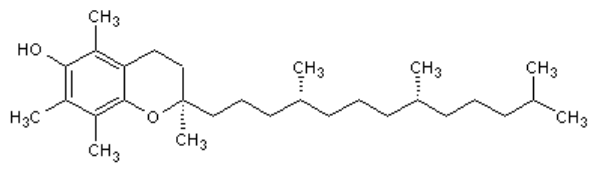

e

$\mathbf{f}$

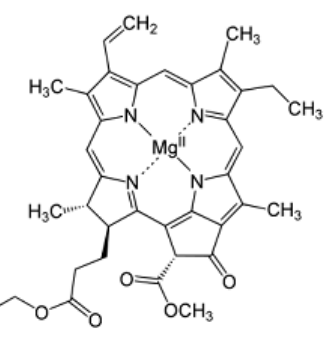

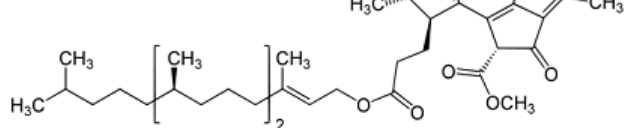

g

h

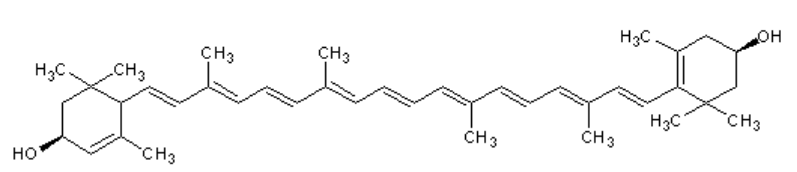

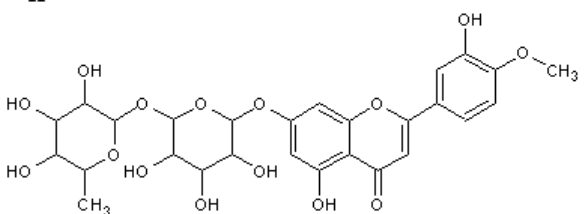

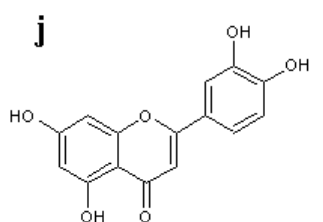<smiles></smiles> 
Figure 2: Chemical structures of T. arjuna compounds with cardiovascular effects: (a) $\beta$-sitosterol, (b) terminic acid, (c) terminoside A, (d) arjunolone, (e) bicalein, (f) pelorgonidin, (g) punicallin, (h) terchebulin, (i) terflavin, (j) castalagin.

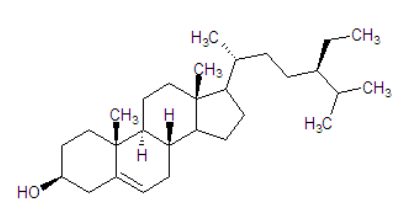

a
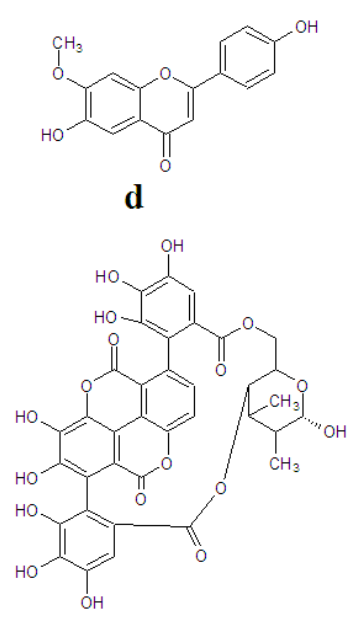

g

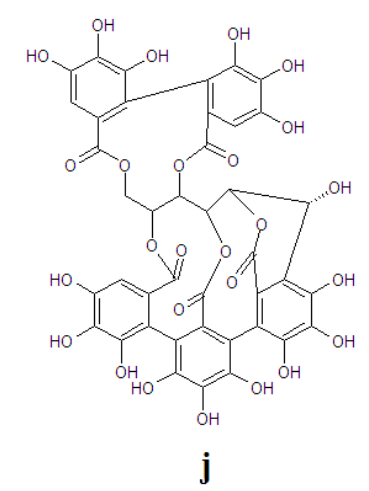

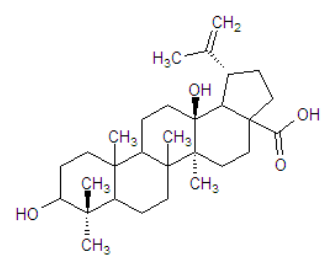

b

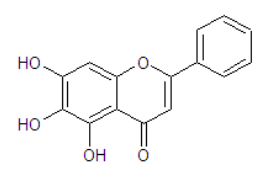

e

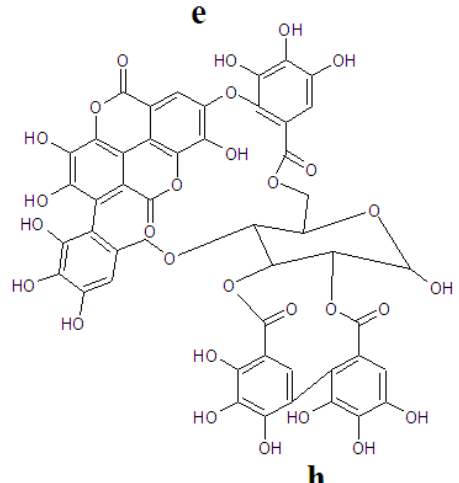

h

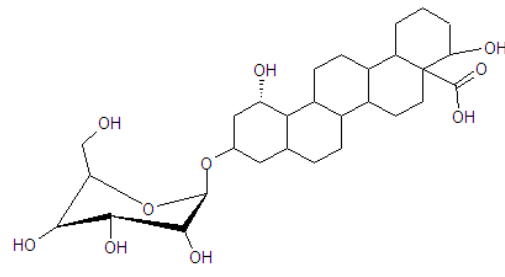

c
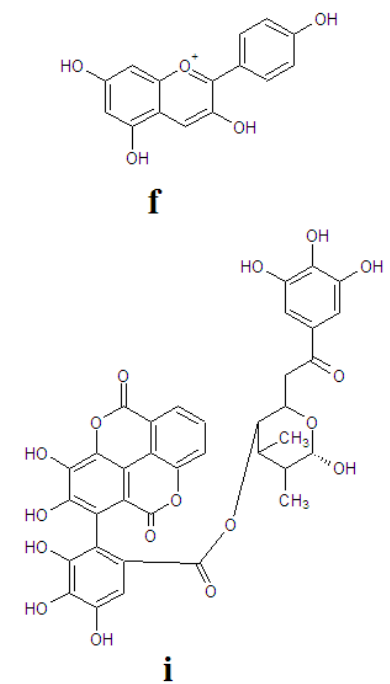

i 
Figure 3: Chemical structures of Terminalia compounds with antimicrobial activity: (a) friedelin, (b) gallic acid, (c) ellagic acid, (d) casuarinin, (e) chebulagic acid, (f) punicalagin.

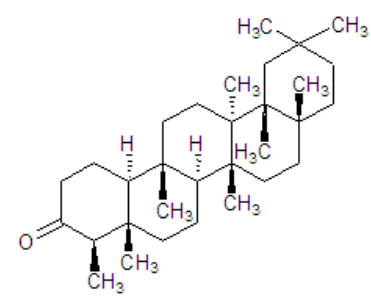

a

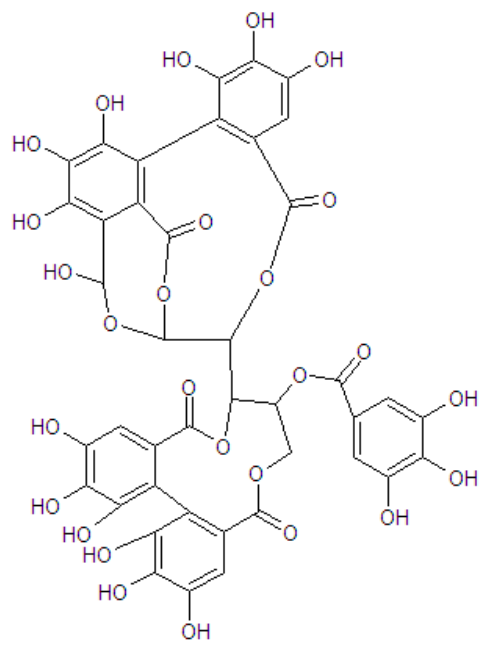

d<smiles>O=C(O)c1cc(O)c(O)c(O)c1</smiles>

b

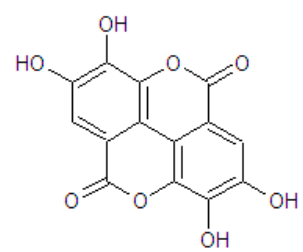

c

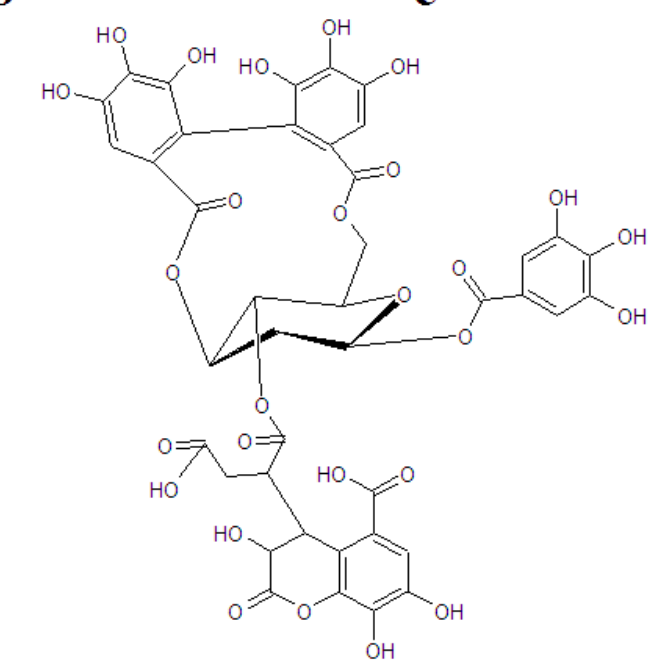

e

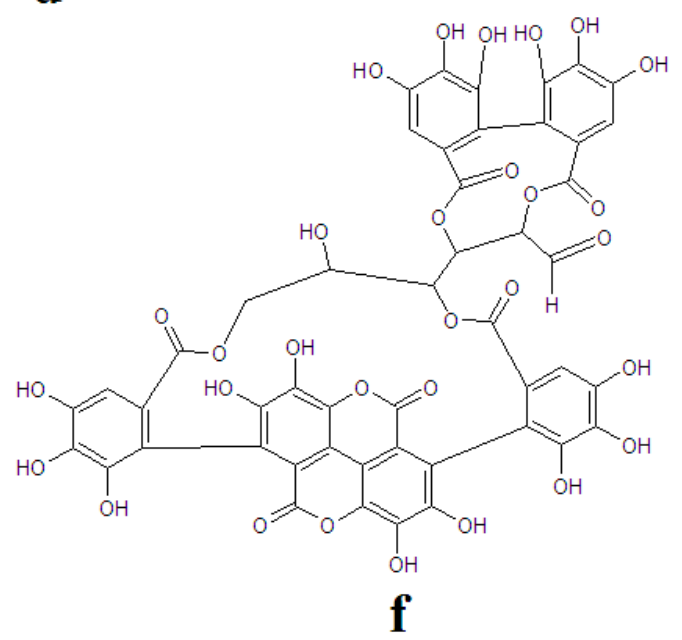


Figure 4: Chemical structures of selected Terminalia compounds with antiinflammatory activity: (a) chebulagic acid, (b) sericoside.

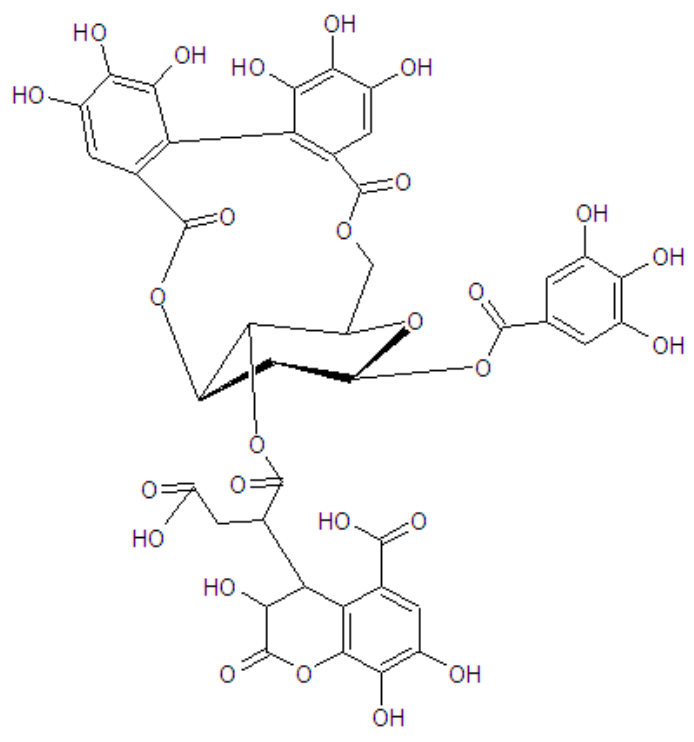

$\mathbf{a}$

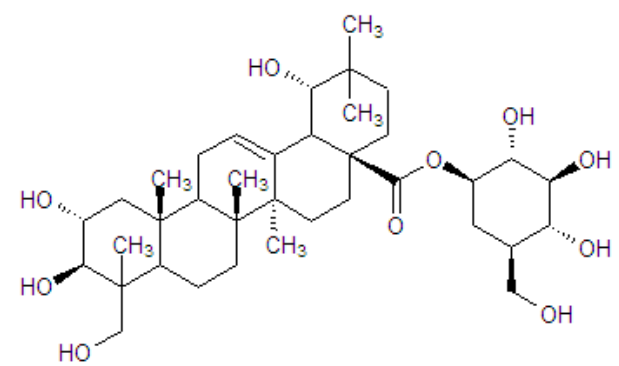

b

Figure 5: Chemical structures of: (a) a $\beta$-sitosterol glucoside, (b) an anthraquinone glycoside.

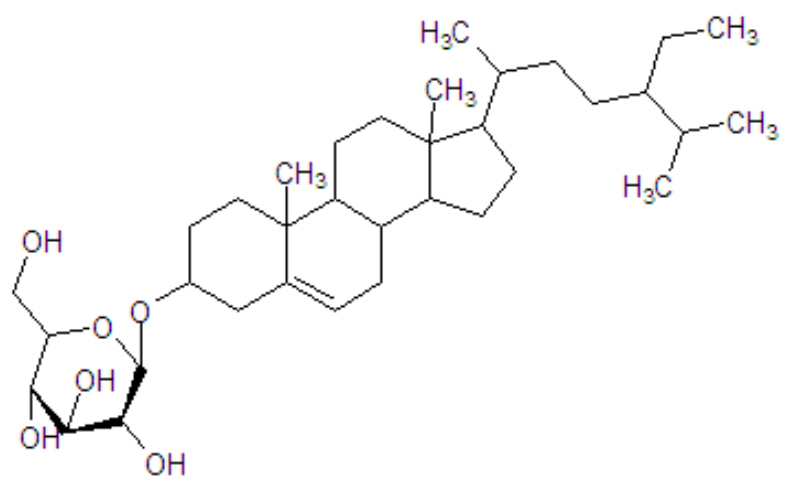

$\mathbf{a}$<smiles>O=C1c2cc(OC3OC(CO)[C@@H](O)[C@H](O)[C@H]3O)cc(O)c2C(=O)c2cc(O)cc(O)c21</smiles> 
Figure 6: Chemical structures of Terminalia compounds with antidiabetes activity: (a) arjunic acid, (b) arjungenin, (c) $\beta$-sitosterol-3-acetate, (d) lupeol, (e) catechin, (f) epicatechin, (g) gallocatechin, (h) epigallocatechin, (i) chebulinic acid.

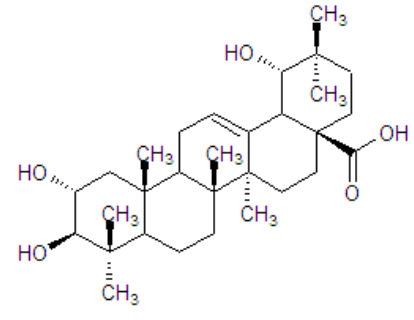

a

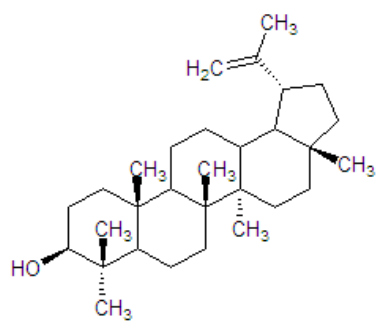

d<smiles>Oc1cc(O)c2c(c1)O[C@H](c1cc(O)c(O)c(O)c1)[C@H](O)C2</smiles>

g

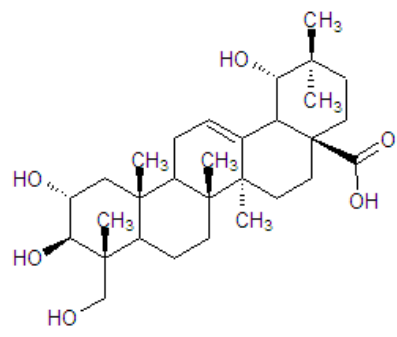

b<smiles>Oc1cc(O)c2c(c1)O[C@H](c1ccc(O)c(O)c1)C(O)C2</smiles>

e<smiles>Oc1cc(O)c2c(c1)O[C@H](c1cc(O)c(O)c(O)c1)[C@H](O)C2</smiles>

h<smiles>CCC(CCC(C)[C@H]1CCC2C3CC=C4C[C@@H](OC(C)=O)CC[C@]4(C)C3CC[C@]21C)C(C)C</smiles>

c<smiles>Oc1cc(O)c2c(c1)O[C@H](c1ccc(O)c(O)c1)[C@H](O)C2</smiles>

$\mathbf{f}$<smiles>CC1C(=O)Oc2c(O)c(O)cc(C(=O)OC3C(OC(=O)C(CC(=O)O)C4c5cc(O)c(O)c(O)c5OC(=O)C4C)C(OC(=O)c4cc(O)c(O)c(O)c4)[C@@H](COC(=O)c4cc(O)c(O)c(O)c4)O[C@H]3OC(=O)c3cc(O)c(O)c(O)c3)c21</smiles>

i 
Figure 7: Chemical structures of selected Terminalia compounds with neuroprotective activity: (a) tannic acid, (b) ethyl gallate, (c) chebulic acid, (d) corilagin.<smiles>O=C(Oc1cc(O)c(O)c(O)c1)c1cc(OC(=O)c2cc(O)c(O)c(O)c2)cc(C(=O)O[C@H]2OC(OC(=O)c3cc(O)c(O)c(OC(=O)c4cc(O)c(O)c(O)c4)c3)[C@H](OC(=O)c3cc(O)c(O)c(OC(=O)c4cc(O)c(O)c(O)c4)c3)[C@H](OC(=O)c3cc(O)c(O)c(OC(=O)c4cc(O)c(O)c(O)c4)c3)[C@H]2OC(=O)c2cc(O)c(O)c(O)c2)c1</smiles>

$\mathbf{a}$<smiles>O=C(O[C@@H]1OC2COC(=O)c3cc(O)c(O)c(O)c3-c3c(cc(O)c(O)c3O)C(=O)O[C@H](C2O)[C@@H]1O)c1cc(O)c(O)c(O)c1</smiles><smiles>CCOC(=O)c1cc(O)c(O)c(O)c1</smiles>

b<smiles>C=C1O[C@H](C(=O)O)[C@H](C(=O)O)c2c1cc(O)c(O)c2O</smiles>

c 
Table 1: A summary of the origin, medicinal properties, and phytochemical constituents (where known) for selected Terminalia species worldwide.

\begin{tabular}{|c|c|c|c|c|}
\hline Species & Common name & Origin & Medicinal properties & Known cor \\
\hline $\begin{array}{l}\text { Terminalia } \\
\text { acuminata }\end{array}$ & $\begin{array}{l}\text { Abalo, } \\
\text { Darot,Biiris,Mbarao,Weiba }\end{array}$ & Brazil & $\begin{array}{l}\text { treatment of yellow } \\
\text { fever, pink eye, hepatitis }\end{array}$ & high tannin \\
\hline $\begin{array}{l}\text { Terminalia } \\
\text { altissima }\end{array}$ & White afara & $\begin{array}{l}\text { Tropical west } \\
\text { Africa, Sierra } \\
\text { Leone, Congo, } \\
\text { Nigeria, } \\
\text { Cameroon }\end{array}$ & $\begin{array}{l}\text { None known. Mainly } \\
\text { used for its quality wood }\end{array}$ & Unknown \\
\hline $\begin{array}{l}\text { Terminalia } \\
\text { amazonia }\end{array}$ & White olive & South America & $\begin{array}{l}\text { None known. Mainly } \\
\text { used for its quality wood }\end{array}$ & Unknown \\
\hline $\begin{array}{l}\text { Terminalia } \\
\text { arbuscula }\end{array}$ & White olive & $\begin{array}{l}\text { Jamaica and the } \\
\text { Carribean region }\end{array}$ & $\begin{array}{l}\text { None known. Mainly } \\
\text { used for its quality wood }\end{array}$ & Unknown \\
\hline $\begin{array}{l}\text { Terminalia } \\
\text { arenicola }\end{array}$ & Brown Damson & Australia & None known & Unknown \\
\hline
\end{tabular}




\begin{tabular}{|c|c|c|c|c|}
\hline Terminalia arjuna & $\begin{array}{l}\text { Arjuna, Koha, White } \\
\text { Marudah }\end{array}$ & $\begin{array}{l}\text { India, Sri Lanka } \\
\text { and Southern Asia }\end{array}$ & $\begin{array}{l}\text { Analgesic, } \\
\text { antiinflammatory, } \\
\text { antioxidant, cardiac } \\
\text { stimulant, } \\
\text { antihypertensive, } \\
\text { astringent, increases } \\
\text { cholesterol elimination }\end{array}$ & $\begin{array}{l}\text { Triterpenoids, } \\
\text { flavonoids, tannins, } \\
\text { gallic and ellagic acid, } \\
\text { sitosterol, } \\
\text { proanthocyanidins }\end{array}$ \\
\hline $\begin{array}{l}\text { Terminalia } \\
\text { australis }\end{array}$ & Palo amarillo, Tanimbu & South America & Antiseptic, antifungal & $\begin{array}{l}\text { Triterpenes, flavonoids, } \\
\text { tannins }\end{array}$ \\
\hline $\begin{array}{l}\text { Terminalia } \\
\text { avicennioides }\end{array}$ & Kpace, kpayi, baushe & West Africa & $\begin{array}{l}\text { Treatment of cough, } \\
\text { bloody sputum, } \\
\text { antimycobacterial } \\
\text { activity }\end{array}$ & $\begin{array}{l}\text { ellagic acid, } \\
\text { punicalagin, } \\
\text { flavogallonic acid and } \\
\text { terchebulin }\end{array}$ \\
\hline $\begin{array}{l}\text { Terminalia } \\
\text { bellirica }\end{array}$ & Beleric & $\begin{array}{l}\text { India and South } \\
\text { East Asia }\end{array}$ & $\begin{array}{l}\text { Expectorant, laxative, } \\
\text { treatment of coughs and } \\
\text { colds, anaemia, diuretic, } \\
\text { anthelmintic, } \\
\text { antipyretic, analgesic, } \\
\text { aphrodisiac, alopecia }\end{array}$ & $\begin{array}{l}\text { The glycoside } \\
\text { bellericanin, gallic acid, } \\
\text { Ellargic Acid, lignans, } \\
\text { 7hydroxy-3,4- } \\
\text { (methylene dioxy)- } \\
\text { flavone, anolignan B, } \\
\text { sitosterol }\end{array}$ \\
\hline $\begin{array}{l}\text { Terminalia } \\
\text { bentzoe }\end{array}$ & $\begin{array}{l}\text { Multiple in different } \\
\text { cultures }\end{array}$ & $\begin{array}{l}\text { Southern Africa, } \\
\text { Reunion Island }\end{array}$ & antimalarial activity & $\begin{array}{l}\text { citronellyl acetate, } \\
\text { flavonoids, triterpenes, } \\
\text { tannins }\end{array}$ \\
\hline
\end{tabular}




\section{Terminalia bialata Indian silver greywood}

\section{Terminalia}

brachystemma

Terminalia

brownii

\section{Terminalia}

buceras

Terminalia

bursarina

Terminalia

calamansanai

Terminalia

catappa

Black olive

Yellow wood
India, Southern

Asia

Southern Africa

African cultures $\quad$ Central Africa

Phillipine almond, Anarep

South East Asia, Phillipines

broad distribution

from Australia

and South East

Asia, India to

Africa
Antibacterial, antifungal

Antibacterial,

antifungal, antiviral

None known. Mainly used for its quality wood tannins

Triterpenes, flavonoids, tannins

Sitosterol, stigmasterol, triterpenes, flavonoids, tannins

Triterpenes, flavonoids, tannins

\section{None known but} reported toxicity

\section{Unknown}

Astringent, lithotriptic

Ellagitannins, phenolic compounds, gallic acid

Treatment of liver

disease (Taiwan),

dysentry and diarrhoea flavoioids (including

(Suriname), antioxidant kaempferol, quercetin),

and anticancer activity, tannins, saponins and

activity against phytosterols

chloroquine resistant

Plasmodium falciparum 


\begin{tabular}{|c|c|c|c|c|}
\hline $\begin{array}{l}\text { Terminalia } \\
\text { chebula }\end{array}$ & $\begin{array}{l}\text { Black Mytrobalan, } \\
\text { Chebulic Myrobalan, } \\
\text { Inknut }\end{array}$ & $\begin{array}{l}\text { Southern Asia, } \\
\text { from India to } \\
\text { Nepal, China, Sri } \\
\text { Lanka, Malaysia, } \\
\text { Vietnam }\end{array}$ & $\begin{array}{l}\text { anti-tumour activity, eye } \\
\text { disorders, treatment of } \\
\text { coughs and colds, } \\
\text { digestive disorders, } \\
\text { inflammation, } \\
\text { anthelmentic, } \\
\text { cardiotonic, aphrodisiac, } \\
\text { tonic }\end{array}$ & $\begin{array}{l}\text { terflavin B and } \\
\text { chebulinic acid }\end{array}$ \\
\hline Terminalia citrina & $\begin{array}{l}\text { Yellow myrobalan, } \\
\text { Manahei }\end{array}$ & India, South Asia & Duiretic, Cardio-tonic & $\begin{array}{l}\text { Triterpenes, flavonoids, } \\
\text { tannins }\end{array}$ \\
\hline $\begin{array}{l}\text { Terminalia } \\
\text { coriacea }\end{array}$ & Leathery Murdah & India & $\begin{array}{l}\text { cardiac stimulant, } \\
\text { accelerates wound } \\
\text { healing, diarrhoea, } \\
\text { antioxidant activity }\end{array}$ & $\begin{array}{l}\text { alkaloids, flavonoids, } \\
\text { glycosides, saponins, } \\
\text { sterols, tannins, } \\
\text { triterpenoids and } \\
\text { phenolic compounds }\end{array}$ \\
\hline $\begin{array}{l}\text { Terminalia } \\
\text { elliptica }\end{array}$ & Indian laurel & $\begin{array}{l}\text { South East Asia, } \\
\text { India, Nepal, } \\
\text { Bangladesh, } \\
\text { Myanmar, } \\
\text { Thailand, Laos, } \\
\text { Cambodia, } \\
\text { Vietnam }\end{array}$ & Diarrhoea and dysentry & $\begin{array}{l}\text { Oxalic acid, pyrogallol, } \\
\text { catechol }\end{array}$ \\
\hline
\end{tabular}




\begin{tabular}{|c|c|c|c|c|}
\hline $\begin{array}{l}\text { Terminalia } \\
\text { eriostachya }\end{array}$ & Black Mastic & $\begin{array}{l}\text { Cuba, Cayman } \\
\text { Islands }\end{array}$ & antiseptic properties & unknown \\
\hline $\begin{array}{l}\text { Terminalia } \\
\text { ferdinandiana }\end{array}$ & Kakadu plim, gubinge & Australia & $\begin{array}{l}\text { High qantioxidant } \\
\text { activity, treatment of } \\
\text { coughs and colds, } \\
\text { antiseptic, antibacterial, } \\
\text { antifugal, anticancer, } \\
\text { antiinflammatory } \\
\text { activities }\end{array}$ & $\begin{array}{l}\text { high ascorbic and gallic } \\
\text { acid contents, } \\
\text { triterpenes, flavonoids, } \\
\text { tannins }\end{array}$ \\
\hline $\begin{array}{l}\text { Terminalia } \\
\text { glaucescens }\end{array}$ & $\begin{array}{l}\text { Multiple names in different } \\
\text { African cultures }\end{array}$ & Tropical Africa & $\begin{array}{l}\text { treatment of diabetes, } \\
\text { dysentry, diarrhoea, } \\
\text { venereal diseases, } \\
\text { analgesic }\end{array}$ & $\begin{array}{l}\text { Triterpenes, flavonoids, } \\
\text { tannins }\end{array}$ \\
\hline $\begin{array}{l}\text { Terminalia } \\
\text { grandiflora }\end{array}$ & Nut tree & Australia & $\begin{array}{l}\text { High qantioxidant } \\
\text { activity, treatment of } \\
\text { coughs and colds, } \\
\text { antiseptic, antibacterial, } \\
\text { antifugal, anticancer, } \\
\text { antiinflammatory } \\
\text { activities }\end{array}$ & $\begin{array}{l}\text { high ascorbic and gallic } \\
\text { acid contents, } \\
\text { triterpenes, flavonoids, } \\
\text { tannins }\end{array}$ \\
\hline
\end{tabular}




\section{Terminalia \\ ivorensis \\ Idigbo, Black Afara, Blackbark, Brimstone \\ Wood, Shingle Wood}

Terminalia

kaernbachii

Terminalia

macroptera

\section{Terminalia}

mauritana

Terminalia mollis
Indian almond

Okari Nut

Bayankada

Bush willow
Western Africa,

Cameroon, Ivory

Coast, Ghana,

Liberia, Nigeria,

Sierra Leone

Papua New

Guinea, Solomon

Islands

Tropical West

Africa

broad distribution

from Australia

and South East

Asia, India to

Africa

antimalarial activity,

treatment of

trypanosomiasis

None known. Mainly

used for its quality wood

Unknown

Antiseptic, treatment of sexually transmitted

diseases

\section{Ellagitannins, phenolic} compounds

\section{Treatment of liver}

disease (Taiwan),

dysentry and diarrhoea

(Suriname), antioxidant

and anticancer activity,

activity against

chloroquine resistant

Plasmodium falciparum

Antiseptic, antifungal,

Southern Africa

Triterpene saponins (including ivorenosides A, B and C), flavonoids, tannins

flavoioids (including kaempferol, quercetin), tannins, saponins and phytosterols antimalarial, anti-HIV activity
Triterpenes, flavonoids, tannins 
Terminalia

muelleri

Terminalia

myriocarpa

Tolhao, Mezok, Panisoj

South East Asia

iuretic, Antioxidan

cardiac stimulant,

treatment of chest pains

-orientin,

kaempferol 3-O- $\beta$-D-

rutinoside, rutin,

neosaponarin, ellagic

acid, flavogallonic acid

and $(\alpha / \beta)$-punicalagin

None reported but there Ellagitannins, phenolic are reports of toxicity
Terminalia

Rosewood, yellow-wood
Australia 


\begin{tabular}{|c|c|c|c|c|}
\hline $\begin{array}{l}\text { Terminalia } \\
\text { paniculata }\end{array}$ & Vellamaruth & India & $\begin{array}{l}\text { treatment of cholera, } \\
\text { inflammation, menstral } \\
\text { disorders, cough, } \\
\text { bronchitis, cardiac } \\
\text { disorders, diabetes, } \\
\text { wounds, skin diseases }\end{array}$ & $\begin{array}{l}\text { phenols, coumarins, } \\
\text { lignans, essential oil, } \\
\text { monoterpenes, } \\
\text { carotinoids, glycosides, } \\
\text { f }\end{array}$ \\
\hline $\begin{array}{l}\text { Terminalia } \\
\text { parviflora }\end{array}$ & $\begin{array}{l}\text { Indian almond, tropical } \\
\text { almond, umbrella tree }\end{array}$ & Sri Lanka & $\begin{array}{l}\text { Treatment of liver } \\
\text { disease (Taiwan), } \\
\text { dysentry and diarrhoea } \\
\text { (Suriname), antioxidant } \\
\text { and anticancer activity, } \\
\text { activity against } \\
\text { chloroquine resistant } \\
\text { Plasmodium falciparum }\end{array}$ & $\begin{array}{l}\text { flavoioids (including } \\
\text { kaempferol, quercetin), } \\
\text { tannins, saponins and } \\
\text { phytosterols }\end{array}$ \\
\hline $\begin{array}{l}\text { Terminalia } \\
\text { prunioides }\end{array}$ & $\begin{array}{l}\text { Purple pod Terminalia, } \\
\text { Sterkbos, Hareri, } \\
\text { Mwangati }\end{array}$ & $\begin{array}{l}\text { Southern Africa } \\
\text { from South Africa } \\
\text { to Ethiopa }\end{array}$ & $\begin{array}{l}\text { Relief of postnatal } \\
\text { abdominal pain }\end{array}$ & $\begin{array}{l}\text { Triterpenes, flavonoids, } \\
\text { tannins }\end{array}$ \\
\hline $\begin{array}{l}\text { Terminalia } \\
\text { schimperiana }\end{array}$ & Idi odan & $\begin{array}{l}\text { Tropical Africa, } \\
\text { Guinea, Sierra } \\
\text { Leone, Uganda, } \\
\text { Ethiopia }\end{array}$ & $\begin{array}{l}\text { Antiseptic, oral hygeine, } \\
\text { antibacterial and } \\
\text { antifungal properties }\end{array}$ & $\begin{array}{l}\text { Triterpenes, flavonoids, } \\
\text { tannins }\end{array}$ \\
\hline
\end{tabular}




\section{Terminalia sericea Silver Terminalia, Mususu, Vaalboom \\ Terminalia \\ spinosa \\ Kasansa, Spiny cluster leaf, Musosahwai}

\section{Terminalia \\ stenostachya}

\section{Terminalia}

subspathulata

\section{Talisei}

Terminalia

superba
Southern Africa

Stomach ailments,

treatment of bilharzia, Stilbene glycosides

diarrhoea, pneumonia, phenolic compounds

diabetes, antiseptic

abdominal disorders,

pain, bilharzia, anncer,

coughs and colds,

dysentry, diarrhoea,

fever, venereal diseases,

Triterpenes, flavonoids,

Southern Africa

heart disorders,

hypertension, jaundice,

diabetes, antiseptic

abdominal disorders,

pain, bilharzia, anncer,

coughs and colds,

dysentry, diarrhoea,

Triterpenes, flavonoids,

Southern Africa

heart disorders,

hypertension, jaundice,

diabetes, antiseptic

Malaysia and

Indonesia

Tropical Western

Africa
None known. Mainly

used for its quality wood

Triterpenes, flavonoids, tannins

None known. Mainly

used for its quality wood

Unknown 
Terminalia triflora None found

Tropical South

America,

Argentina antibacterial and

antifungal activity, $\quad$ Ellagitannins, phenolic

reputed anti-HIV

activity compounds

Ethnopharmacological uses, constituents and common names are derived from searches of Google Scholar and PubMed atabases. 